\title{
Working
}

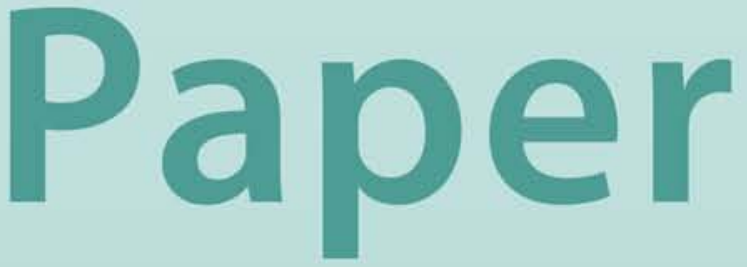




\section{Asymmetric Effects of Government Spending: Does the Level of Real Interest Rates Matter?}

Woon Gyu Choi and Michael B. Devereux 


\title{
IMF Working Paper
}

IMF Institute

\section{Asymmetric Effects of Government Spending: Does the Level of Real Interest Rates Matter?}

\author{
Prepared by Woon Gyu Choi and Michael B. Devereux ${ }^{1}$ \\ Authorized for distribution by Sunil Sharma
}

January 2005

\begin{abstract}
This Working Paper should not be reported as representing the views of the IMF. The views expressed in this Working Paper are those of the author(s) and do not necessarily represent those of the IMF or IMF policy. Working Papers describe research in progress by the author(s) and are published to elicit comments and to further debate.

This paper empirically explores how fiscal policy (represented by increases in government spending) has asymmetric effects on economic activity at different levels of real interest rates. It suggests that the effect of fiscal policy depends on the level of real rates, since the Ricardian effect is smaller at lower financing costs of fiscal policy. Using threshold regression models on U.S. data, the paper provides new evidence that expansionary government spending is more conducive to short-run growth when real rates are low. It also finds asymmetric effects on interest rates and inflation, and threshold effects associated with substitution between financing methods.
\end{abstract}

JEL Classification Numbers: C32; C51; E62

Keywords: fiscal policy; government spending; Ricardian equivalence; real interest rates; regime switching; threshold vector autoregression

Author(s) E-Mail Address: wchoi@imf.org; devm@interchange.ubc.ca

\footnotetext{
${ }^{1}$ Woon Gyu Choi is a Senior Economist at the IMF Institute of the International Monetary Fund. Michael B. Devereux is a professor of economics at the University of British Columbia. The authors thank Tamim Bayoumi, Andrew Feltenstein, Iryna Ivaschenko, Sung In Jun, Sunil Sharma, and seminar participants in the 2004 Far Eastern Meeting of the Econometric Society in Seoul (June 30-July 2) for useful comments and discussions.
} 
Contents Page

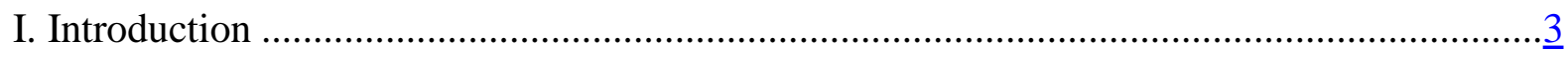

II. Relevant Literature on the Effectiveness of Fiscal Policy ............................................ $\underline{5}$

III. Empirical Model Specification and Estimation Methodology........................................... $\underline{8}$

A. Asymmetric Effects of Government Spending .................................................. $\frac{8}{8}$

B. A Threshold Vector Autoregression (TVAR) Model …...........................................

C. Nonlinearity Testing and Number of Thresholds............................................... 9

D. Specification Tests for Asymmetry Across Regimes ........................................

E. Analysis of a TVAR Model.........................................................................

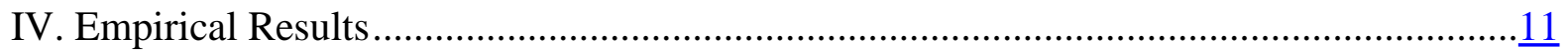

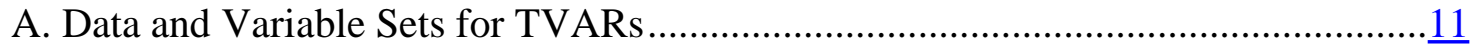

B. Tests for Threshold Effects ...........................................................................14

C. TVAR Models and Impulse Responses to a Government Spending Shock ............. $\underline{\underline{20}}$

D. Robustness Checks and Discussion ................................................................

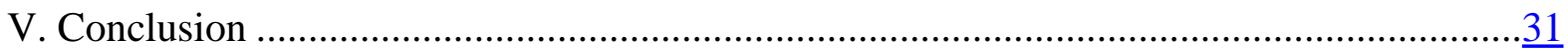

Appendix: Data Sources and the Description of the Variables..........................................

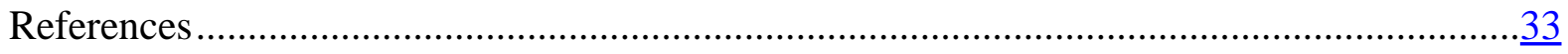

Tables

1. Tests for a Single Threshold and Threshold Estimates...............................................15

2. Tests for a Double Threshold and Threshold Estimates ...............................................16

3. Specification Tests for Asymmetry in TVARs ........................................................ 18

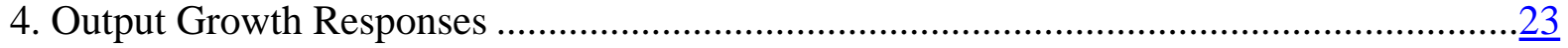

5. Output Growth Responses with Ex Ante Real Rates as Switching Index .........................

Figures

1. Real Interest Rates, Debt-to-GDP Ratio, and Growth in Government Spending ................12

2. Regime Type Index, Real Interest Rates, and Output Growth .....................................19

3. Impulse Responses of Real Activity in Model 1 ....................................................

4. Impulse Responses of Real Activity in Model 2 ........................................................22

5. Impulse Responses of Nominal Interest Rates and Inflation in Model 2 .........................25

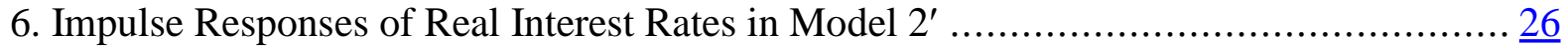

7. Impulse Responses of Financing Methods in Models 1 and 2 ...................................... 


\section{INTRODUCTION}

Postwar data for the United States exhibit substantial fluctuations in real interest rates. Shifts in real interest rates affect the cost of financing government spending and the burden of future fiscal consolidation. Hence, the effect of fiscal policy may depend on the level of real interest rates to the extent that the negative impact from the Ricardian effect is smaller when real rates are low than when they are high. This paper empirically explores how fiscal policy (represented by increases in government spending) has asymmetric effects on economic activity at different levels of real interest rates.

Why might the effectiveness of fiscal policy depend on the real interest rate? In standard dynamic-general-equilibrium models, the government spending multiplier is sensitive to the assumptions made about labor supply, the persistence of the spending shock, and other features of the economic environment. Fiscal policy shocks have positive effects on output and investment through various channels, which are principally related to intertemporal substitution and wealth effects on labor supply. These models, however, examine the local effects of fiscal policy shocks approximated around a steady state where the real interest rate is constant. In general, therefore, these models abstract from the financing consequences of fiscal policy shocks, assuming that whether increased spending is financed by taxes or by debt does not affect the size of the multiplier. Even in dynamic models that do not satisfy Ricardian equivalence, the fiscal policy multipliers are normally quite close to those in the usual dynamic-generalequilibrium model with an infinite horizon (see Barry and Devereux, 2003).

Recent research has emphasized that the financing consequences of fiscal policy may be of key importance. In particular, a large literature on the possibility of contractionary effects of fiscal policy has argued that, in times of large deficits and growing public debt, government spending can have weak or even negative effects by affecting expectations about future taxes. Government spending and public debt could reach a level at which further spending causes a precipitous fall in consumption by triggering expectations of a fiscal crisis. A number of papers have modeled the way in which fiscal policy can have counterproductive outcomes through this mechanism: for example, one strand of the literature proposes the "expansionary fiscal contraction" hypothesis (Barry and Devereux, 1995, 2003; Sutherland, 1997; Perotti, 1999).

Standard debt-sustainability analysis (for example, Reinhart, Rogoff, and Savastano, 2003), as applied to a country's government debt, suggests that real interest rates should be lower than the rate of output growth if the fiscal position is to be sustainable; otherwise the debt dynamics may lead to an untenable situation. However, a virtuous cycle can emerge in which low real interest rates and rapid growth reduce the economy's fiscal debt burden. Ball, Elmendorf, and Mankiw (1998) suggest that the future effects of government spending can be benign, depending on real interest rates and output growth. If the average return on government debt is sufficiently below the average rate of output growth for a sufficiently long period, the government can roll over the debt and accumulated interest without raising taxes, since output will likely grow faster than the debt will accumulate. Conversely, if the rate of future economic growth turns out to be low relative to the return on the debt, the debt-output ratio will increase, and eventually the government will be forced to raise taxes. 
Real interest rates show substantial fluctuations over time (see, for example, Garcia and Perron, 1996). Shifts in real interest rates can be associated with shifts in productivity or in time preferences. They can also be caused by exogenous structural events, such as changes in the monetary regime or deregulation of interest rates. Canzoneri and Dellas (1998) show that the choice of operating target procedures affects real interest rates in a stochastic general equilibrium: interest rate targeting results in higher real rates than does monetary aggregate targeting. These authors conjecture that the higher are real interest rates, the more costly it is to finance the existing public debt, and, ultimately, the more taxes have to be raised.

In this paper, we find that the effectiveness of government spending in stimulating economic activity tends to be critically related to the level of real interest rates. When real rates are low, expansionary fiscal policy tends to be effective, raising output and its components, investment and consumption. Conversely, when real rates are high, the effect of expansionary fiscal policy on the same aggregates tends to be weaker or even negative. The intuition behind this result is as follows. Suppose that Ricardian equivalence fails, so that the financing implications of government spending are important. Also suppose that there is an upper limit-set by political economy considerations - on the debt-output ratio that a government can tolerate. If the debt ratio is expected to reach this upper limit, which happens when real interest rates are very high relative to output growth, economic agents perceive that fiscal consolidation will be necessary and expect higher future tax rates on wages and capital income. Therefore, the impact of government spending will be very different, depending on whether real interest rates are high enough for the economy to exceed the tolerable debt burden over the agents' time horizon.

The level of real interest rates is thus a key determinant of the impact of government spending. A persistent shock to government spending affects the probability of hitting the upper limit on the debt ratio and thus the probability of a future fiscal adjustment. Private decisions about consumption and investment in response to a fiscal expansion therefore depend on whether the real interest rate is high or low relative to output growth. When real interest rates are low, a fiscal expansion that is financed by deficits rather than current taxes raises the outstanding stock of public debt, but this does not generate a significant risk of hitting the upper limit on the debtoutput ratio. When real rates are high, however, the same fiscal expansion is more likely to push government debt toward the upper limit within the agents' time horizon. As a result, such a fiscal expansion tends to have a strongly negative effect on aggregate consumption and investment. The effect of the fiscal expansion on output is then much smaller than it would be in a period of low real interest rates. Therefore, the size of the Ricardian effect will depend (positively) on the level of real interest rates.

Many recent studies have examined the effect of fiscal policy shocks based on government spending (for example, Blanchard and Perotti, 2002; Alesina and others, 2002; Fatás and Mihov, 2003). Changes in government spending are typically associated with changes in government debt rather than in the tax rate, since government debt is typically managed so as to maintain a pattern of reasonably stable tax rates over time, although there could be situations in which the size of the government debt and associated interest payments force the government to raise 
taxes. ${ }^{2}$ Following this line of research, we focus exclusively on government spending in assessing the effect of fiscal policy. Also, we look at asymmetric effects of government spending. Earlier studies have searched for nonlinear effects of fiscal policy based on the characteristics of the fiscal impetus that have implications for future tax liabilities (Giavazzi, Jappelli, and Pagano, 2000; Alesina and others, 2002; Bayoumi and Masson, 1998) or on consumers' expectations about future fiscal adjustment to achieve debt sustainability (Bertola and Drazen, 1993; Sutherland, 1997; Perotti, 1999). Our search for nonlinear effects takes a slightly different approach.

We employ threshold regression methods (Tong, 1990; Choi, 1999; Hansen, 1999, 2000) to examine nonlinearities in the effect of government spending that arise from shifts in the cost of financing. Our specification allows government spending shocks to have different effects on economic activity, depending on the level of real interest rates. The results obtained using U.S. time series data suggest that asymmetry in fiscal policy effects is associated with nonlinearity in the behavior of investment growth, output growth, and interest rates across different levels of real interest rates. Linearity testing supports the existence of a double threshold (that is, three regimes), and impulse-response analysis reveals pronounced asymmetries in the dynamic response of the economy to a government spending shock.

We provide new evidence that expansionary government spending is conducive to spurring growth in the short run when an economy faces comparatively low real interest rates. We also find asymmetric effects of government spending on nominal and real rates of interest: there are positive effects on nominal interest rates when real interest rates are low, but negative effects on nominal and real interest rates when interest rates are sufficiently high, in accord with earlier studies (Evans, 1985, 1987; Mankiw, 1987). In addition, we find positive inflation responses to government spending only when real interest rates are sufficiently low, which reconciles the cross-country evidence of recent studies (Koelln, Rush, and Waldo, 1996; Fischer, Sahay, and Végh, 2002; Catão and Terrones, 2003). Further, we provide some evidence on threshold effects associated with substitution between government debt and money for financing government spending in the face of different levels of real interest rates.

The remainder of this paper is organized as follows. Section II briefly describes the related literature. Section III presents the empirical model specifications and the estimation methodology. Section IV reports the empirical results on the asymmetric effects of government spending and examines the robustness of these results. Section V concludes.

\section{Relevant Literature ON The EfFectiveness of Fiscal Policy}

In a simple Keynesian framework that assumes price rigidity and the possibility of excess capacity, a fiscal expansion has a multiplier effect on output. If government spending increases interest rates, it reduces private spending through the crowding-out effect and thus dampens the

\footnotetext{
${ }^{2}$ Davig, Leeper, and Chung (2004) suggest that tax policy reactions can shift between periods when taxes are adjusted in response to government indebtedness and periods when other priorities drive tax decisions. We focus on government spending and its implications for future tax liabilities but not on the tax policy behavior itself.
} 
multiplier effect. ${ }^{3}$ Although fiscal policy analysis traditionally focuses on its demand-side effects, there could be supply-side effects that add to the effectiveness of fiscal policy. ${ }^{4}$ Government spending on investment-type goods helps augment production capacity and thus tends to increase the fiscal multiplier by ameliorating the crowding-out effect.

Contrary to the conventional Keynesian view, the "expansionary fiscal contraction" hypothesis suggests that fiscal contractions can, through their impact on expectations, lead to growth in consumption and investment. In this hypothesis, a large or persistent fiscal contraction, after a prevailing expansionary fiscal stance, signals the government's adjustment that has been delayed (Barry and Devereux, 1995; Sutherland, 1997; Perotti, 1999). Such episodic fiscal contractions are more likely to happen in the economies that need a fiscal adjustment (see, for the listing of related studies using cross-country data, Alesina and Perotti 1997; Giavazzi, Jappelli, and Pagano, 2000; Hemming, Kell, and Mahfouz, 2002; Alesina and others, 2002).

A neoclassical approach suggests that the effects of government spending stem mainly from its crowding-out effect and a wealth effect (Barro, 1981; Aiyagari, Christiano and Eichenbaum, 1992; Christiano and Eichenbaum, 1992; Baxter and King, 1993). The wealth effect is operative as long as increases in government spending today imply increases in future taxes. The resulting fall in wealth reduces consumer demand, increases labor supply, and lowers interest rates (Devereux and Love, 1995; Barry and Devereux, 1995), and the increase in labor supply in turn increases the marginal productivity of capital and spurs investment (Ramey and Shapiro, 1998; Burnside, Eichenbaum, and Fisher, 2003). The size of the wealth effect depends on whether the change in government spending has purely transitory or persistent effects.

In the extreme case of complete Ricardian equivalence (Barro, 1974; Evans, 1988), an increase in government spending, regardless of whether financed by higher taxes or by debt, will be fully offset by higher private saving. However, the practical significance of complete Ricardian equivalence is questionable, since it relies on strong assumptions. The empirical literature on Ricardian equivalence has provided mixed results for Ricardian equivalence (for listings of studies, see Evans, 1988; Hemming, Kell, and Mahfouz, 2002). The non- or partial Ricardian equivalence case arises, when agents have a short-time horizon, less than perfect foresight, or binding borrowing constraints (for example, Blanchard, 1985; Mankiw, 2000). In the more realistic case where the private sector does not fully account for or discount the future taxes implied by increased government spending, the Ricardian effect is only partial. In that case, fiscal policy can retain a stabilization role, and the issue of its effectiveness remains.

A fiscal expansion may have effects on interest rates and inflation. Contrary to the hypothesis that higher interest rates caused by the fiscal expansion would have a crowding-out effect, Evans (1987) finds no positive association between budget deficits and real or nominal rates of interest; this finding is consistent with Ricardian equivalence. Mankiw (1987) argues that an increase in government spending depresses the real interest rate, because it reduces private consumption

\footnotetext{
${ }^{3}$ In an open economy, higher interest rates induce capital inflows and real exchange rate appreciations, which result in a deteriorating current account and offset the increase in domestic demand arising from a fiscal expansion. ${ }^{4}$ Public services can be considered as an input to private production, government spending on public goods and infrastructure can lead to faster economic growth (Aschauer, 1989; Barro and Sala-i-Martin, 1992; Tanzi and Zee, 1997). Such supply-side effects of fiscal policy are regarded as more important over the longer term.
} 
(through a wealth effect) and increases the marginal utility of consumption, which lowers the marginal rate of substitution and thus the marginal productivity of capital (through capital accumulation). Government spending can alternatively be financed with money creation, especially by governments running persistent deficits, producing inflation. However, Dwyer (1982) finds no evidence that higher current or past budget deficits raise the price level. Recent analyses of cross-country data suggest that the positive association between fiscal deficits and inflation is strong among high-inflation and developing countries but not among low-inflation and industrial economies (Fischer, Sahay, and Végh, 2000; Catão and Terrones, 2003).

Many empirical studies have examined the effect of changes in government spending that are not related to the current state of the economy and thus are less prone to simultaneity problems. The empirical results on the effect of such spending are rather mixed. Ramey and Shapiro (1998) using postwar U.S. data find that a military buildup decreases consumption (on durables) and increases (nonresidential) investment, a finding consistent with neoclassical models. Blanchard and Perotti (2002), using a structural VAR approach with U.S. data, show that a positive government spending shock has a positive effect on output and consumption but a negative effect on investment. Alesina and others (2002), using panel data from industrial counties, find that spending shocks have a negative effect on investment, a finding consistent with non-Keynesian effects of fiscal adjustment. Perotti (2002) provides evidence on the decline in the potency of government spending over the last twenty years for a group of industrial countries. Fatás and Mihov (2003), using panel data from a large set of countries, find that the use of discretionary fiscal policy induces macroeconomic instability.

Importantly, two strands of studies emphasize nonlinearity in the effect of fiscal policy. One strand focuses on the different characteristics of different kinds of fiscal impetus. Giavazzi, Jappelli, and Pagano (2000) suggest that nonlinear effects (on national saving) are associated with large and persistent fiscal impetus for both industrial and developing countries, whereas Alesina and others (2002) find little evidence that government spending has different impacts (on investment) during large fiscal adjustments than in normal times. Bayoumi and Masson (1998), using Canadian data, show that national fiscal stabilizers have different impacts on the economy than local fiscal stabilizers because they have different implications for future tax liabilities.

The second strand emphasizes consumers' expectations about fiscal adjustment for government debt sustainability. Bertola and Drazen (1993) suggest that, as government spending approaches a critically high level, a nonlinear relationship arises between government spending and private consumption, consistent with the expansionary effects of large cuts in government spending as part of stabilization programs. Sutherland (1997) theoretically and Perotti (1999) empirically examine how the effect of fiscal policy depends on the level of public debt, extreme values of which trigger consumers' expectations of an increase in their future tax liability.

In this paper we adopt a regime switching approach in studying the effects of changes in government spending, reflecting the notion that no single approach-whether traditional Keynesian, neoclassical, or Ricardian equivalence — can always fit the actual data when regime shifts are involved. Our empirical model is designed to capture the different effects of government spending on economic activities across different regimes. 


\section{EMPIRICAL MOdEL SPECIFICATION AND ESTIMATION METHOdOLOGY}

\section{A. Asymmetric Effects of Government Spending}

We consider a situation in which full Ricardian equivalence fails but that agents are partially Ricardian: agents do reduce their spending in the face of an expansionary government spending to the extent that such spending affects agents' expectation of future tax liabilities during the time horizon they regard as relevant. Since partial Ricardian agents do not fully account for the effect of increased government debt on future taxes, government debt is included as part of the stock of their private wealth. Thus, government spending financed by debt can increase consumption through a wealth effect. Also, government spending on public goods and infrastructure can lead to higher productivity and thus higher investment (a productivityenhancing effect). These wealth and the productivity-enhancing effects will be offset partly or fully — depending on the underlying regime—-by the adverse impact of the Ricardian effect.

Debt sustainability critically depends on whether real interest rates are sufficiently lower than the rate of output growth. The processes of real interest rates and output growth evolve over time with uncertainty. When interest rates are sufficiently high relative to output growth so that the economy is likely to be or near the upper limit on the debt-output ratio, increased government spending may have negative effects on the economy, because of the high probability of precipitating a fiscal consolidation during agents' time horizon of interest. Since shifts in real interest rates will be given exogenously, agents will perceive the underlying regime as prevailing for a sufficiently long period. The impact of government spending will be very different depending on whether or not real interest rates are high enough for the economy to exceed the tolerable debt burden during agents' time horizon.

Our regime switching approach allows the behavior of key variables in the economic system and the net effect of government spending to vary over regimes. We classify the underlying states into three regimes based on the level of real interest rates: a "high-rate" regime, a "moderate-rate" regime, and a "low-rate" regime. We estimate a multiple-equation systemthreshold vector autoregression models-comprising regime-dependent, reduced-form equations, especially for government spending, consumption (or investment), output, and interest rates.

\section{B. A Threshold Vector Autoregression (TVAR) Model}

Assuming that all variables are endogenous and that government spending depends on other variables as well as its own past values, we consider a TVAR model with three regimes in a simple, piecewise-linear form (see Tong, 1990; Choi, 1999) as follows:

$$
\begin{aligned}
\boldsymbol{Y}_{t} & =\boldsymbol{A}_{1}+\boldsymbol{B}_{1}(\boldsymbol{L}) \boldsymbol{Y}_{t-1}+\boldsymbol{V}_{1, t} & & \text { if } s_{t} \leq \tau_{L}, \\
& =\boldsymbol{A}_{2}+\boldsymbol{B}_{2}(\boldsymbol{L}) \boldsymbol{Y}_{t-1}+\boldsymbol{V}_{2, t} & & \text { if } \tau_{L}<s_{t} \leq \tau_{U}, \\
& =\boldsymbol{A}_{3}+\boldsymbol{B}_{3}(\boldsymbol{L}) \boldsymbol{Y}_{t-1}+\boldsymbol{V}_{3, t} & & \text { if } s_{t}>\tau_{U},
\end{aligned}
$$

where $\boldsymbol{Y}_{t}=\left(Y_{t}^{1}, \cdots, Y_{t}^{k}\right)^{\prime}$ is a vector of $k$ variables, $\boldsymbol{L}$ is the lag operator, $\boldsymbol{V}_{i, t}=\left(\varepsilon_{i, t}^{1}, \varepsilon_{i, t}^{2}, \cdots \varepsilon_{i, t}^{k}\right)^{\prime}$ is a $k \times 1$ vector of error terms with $V_{i, t} \sim N\left(0, \Sigma_{V_{i}}\right)$ for $i=1,2,3, s_{t}$ is the switching index, and the 
thresholds are ordered $\left(\tau_{L}<\tau_{U}\right)$. Coefficients, denoted by $\boldsymbol{A}_{i}$ and $\boldsymbol{B}_{i}$, vary across regimes. Errors are assumed to be heteroskedastic across regimes. Threshold parameters, $\tau_{L}$ and $\tau_{U}$, are assumed to be fixed and should be estimated.

\section{Nonlinearity Testing and Number of Thresholds}

If one or more of individual equations in the system involve threshold effects, such threshold effects can feed into the responses of the whole system. Especially if a transmission variable of government expenditures to private spending involves nonlinearity, then government spending can have differential impacts on aggregate demand. For this reason our test of nonlinearity is based on an individual equation rather than for the whole system.

It is well known that classical tests have nonstandard distributions when the threshold parameter is unknown a priori and not identified under the null hypothesis of linearity. This nuisance parameter problem is the so-called Davies problem (Davies, 1987). Following Hansen's $(1999,2000)$ approach to control for the Davies problem, we obtain a consistent estimate of the threshold parameter(s) by minimizing the sum of squared residuals of the equation over a grid set. In the context of the above TVAR model, there are no thresholds, one threshold, or two thresholds. To determine the number of thresholds (and thus of regimes), we perform the likelihood-ratio test, which is nonstandard but free of nuisance parameters, using $p$-values constructed from a bootstrap procedure. Hansen's approach also helps us to obtain the confidence interval for the threshold parameters by forming the no-rejection region using the likelihood-ratio statistic for tests on thresholds.

In the single threshold case, we set the bounded grid set for $\tau \in[\underline{\tau}, \bar{\tau}]$ so that each regime has at least 20 percent of the whole sample. The grid set is composed of 100 grids that evenly divide the range from the 20th to the 80th percentile of the empirical distribution of the switching index. In the two thresholds case, given the first-stage threshold obtained from the estimation of the single threshold model, the grid set for the second threshold is composed of 50 grids, which evenly divide the range of the empirical distribution of the switching index. As suggested by Bai (1997) and Hansen (1999), we use the refinement estimator to improve the efficiency of the threshold parameters by estimating threshold parameters in three stages. ${ }^{5}$

\section{Specification Tests for Asymmetry Across Regimes}

We test the null hypothesis that the coefficients in each equation are equal across three regimes. To deal with the Davies problem, we employ the procedure that approximates the unknown asymptotic distribution by simulation for testing the presence of asymmetry in an individual equation across regimes, following Hansen (1996).

\footnotetext{
${ }^{5}$ In stage 1 we estimate a single threshold $\left(\tau_{1}\right)$. In stage 2 the first-stage threshold is taken as the upper threshold if it is above the 65th percentile of the switching index, and the lower threshold if it is above the 35 th percentile. The grid set for the other threshold $\left(\tau_{2}\right)$ is comprised of 50 grids on one side with the longer leg of the $\tau_{1}$ estimate. If the first-stage threshold is between the 35th and the 65th percentile, the grid set for $\tau_{2}$ is comprised of 25 grids on each side of the $\tau_{1}$ estimate. In stage 3 we take the $\tau_{2}$ estimate as its refinement estimator $\left(\tau_{2}^{r}\right)$ and repeat stage 2 to obtain the refinement estimator of $\tau_{1}\left(\tau_{1}^{r}\right)$.
} 
Following Hansen's procedure, we calculate three test statistics and use simulated realizations of the chi-squared empirical processes underlying these statistics, assuming that the error term is heteroskedastic across regimes but homoskedastic within each regime. The three statistics are functionals of the collection of Wald test statistics over the grid space: the supremum $(\operatorname{Sup} W)$, the average $(A v e W)$, and the exponential average $(\operatorname{Exp} W)$ of all Wald statistics (Davies, 1987; Granger and Teräsvirta, 1993; Ploberger, 1994). Their significance levels are calculated using simulated empirical distributions of these statistics. ${ }^{6}$ In addition, we perform specification tests taking symmetry across given subgroups in the equation as the null hypothesis, as in Durlauf and Johnson (1995). We do this by splitting the data into subgroups based on the assumed $\tau$ and examining whether the coefficients are equal across the subgroups. The $\hat{\tau}$ obtained by the grid search is taken as the assumed $\tau$.

\section{E. Analysis of a TVAR Model}

To find the threshold values of a TVAR model, we employ a grid search, which is useful because our regime switching approach is based on perfect discrimination among regimes and the likelihood function is not differentiable in threshold parameters. For the minimization of the criterion function, the threshold parameter is assumed to be restricted to a bounded set.

The grid search for our TVAR model, in accord with Pesaran and Potter (1997), works as follows. Compared with the refinement estimator of a double threshold, this approach jointly estimates the two threshold parameters, which are assumed to be the same across individual equations in the system. We set grids by generating a $g$-length row vector of the grid for $\tau_{L}$ and $\tau_{U}$, respectively, for its bounded set. The pairwise combinations in $\tau$ form a $g \times g$ grid. We then estimate the TVAR model by least squares for each point in the grid to find the estimate $\hat{\tau}$ that maximizes the conditional log-likelihood and implies estimates $\hat{\boldsymbol{A}}, \hat{\boldsymbol{B}}$, and $\hat{\Sigma}_{V}$. The estimate $\hat{\tau}$ will be consistent, as suggested in Pesaran and Potter (1997) and Hansen (1996). ${ }^{7}$ Let $\tau=\left(\tau_{L}, \tau_{U}\right)^{\prime}$ and $I_{t}(i: \tau)$ be indicator functions with $I_{t}(1: \tau)=I_{t}\left(s_{t} \leq \tau_{L}\right), I_{t}(2: \tau)=I_{t}\left(\tau_{L}<s_{t} \leq \tau_{U}\right)$, and $I_{t}(3: \tau)=I_{t}\left(s_{t}>\tau_{U}\right)$. The conditional log-likelihood up to a constant term is given by

$$
\begin{aligned}
& \ln l\left(\mathbf{A}, \mathbf{B}, \Sigma_{\mathbf{V}}, \tau\right)=-\frac{1}{2} \sum_{t=1}^{T}\left[\sum_{i}^{3} I_{t}(i: \tau) \ln \left|\Sigma_{\mathbf{V}_{i}}\right|\right] \\
& \quad-\frac{1}{2} \sum_{i=1}^{3}\left\{I(i: \tau)\left(\mathbf{Y}^{i}-\mathbf{A}_{i}-\mathbf{B}_{i}(\mathbf{L}) \mathbf{Y}_{-1}^{i}\right)\right\}\left[I_{N i} \otimes \Sigma_{\mathbf{V}_{i}}\right]^{-1}\left\{I(i: \tau)\left(\mathbf{Y}^{i}-\mathbf{A}_{i}-\mathbf{B}_{i}(\mathbf{L}) \mathbf{Y}_{-1}^{i}\right)\right\}
\end{aligned}
$$

\footnotetext{
${ }^{6}$ We generate $J(=1,000)$ realizations of the Wald statistics, $\chi_{T}^{2 j}(\tau) \quad(j=1,2, \ldots, J)$, under the null of symmetry for each grid and then construct empirical distributions for three functionals of the collection of the statistics over the grid space $\Gamma: \operatorname{Sup} W=\sup _{\tau \in \Gamma} \chi_{T}^{2}(\tau), A v e W=\frac{1}{\# \Gamma} \sum_{\tau \in \Gamma} \chi_{T}^{2}(\tau), \operatorname{Exp} W=\ln \left\{\frac{1}{\# \Gamma} \sum_{\tau \in \Gamma} \exp \left(\chi_{T}^{2}(\tau) / 2\right)\right\}$, where $\# \Gamma$ is the number of grid points in the set $\Gamma$.

${ }^{7}$ Hansen's (1999) procedure, by minimizing the sum of squared errors in the threshold autoregressive model, enables one to compute the confidence intervals of thresholds for a single equation. Hansen's procedure for computing confidence intervals, however, is not readily applicable to the thresholds that are obtained by the maximization of the conditional log-likelihood for multiple equations.
} 
where $\Sigma_{V_{i}}=\frac{1}{N_{i}}\left(\boldsymbol{Y}^{i}-\boldsymbol{A}_{i}-\boldsymbol{B}_{i}(\boldsymbol{L}) \boldsymbol{Y}_{-1}^{i}\right)\left(\boldsymbol{Y}^{i}-\boldsymbol{A}_{i}-\boldsymbol{B}_{i}(\boldsymbol{L}) \boldsymbol{Y}_{-1}^{i}\right)^{\prime}, \boldsymbol{Y}^{i}$ is the selected sample vector for regime $i, N_{i}$ is the number of observations in regime $i$, and $I_{N_{i}}$ is an $N_{i} \times N_{i}$ identity matrix.

We construct a total of 1,600 grid sets for $\tau=\left(\tau_{L}, \tau_{U}\right)^{\prime}$, allowing for 40 grids for each threshold: the lower (upper) threshold ranges from the 20th to the 40th percentile, and the upper from the 60th to the 80th percentile, of the empirical distribution of $s_{t}$. We estimate TVARs with the same lag order in all regimes by the least squares method. Then we obtain the impulse response function of the variables of interest to the orthogonal fiscal shock obtained through the Choleski decomposition of $\Sigma_{V_{i}}$, assuming that the economy stays within its initial regime.

Empirical standard error bounds for the response function are obtained using the bootstrap method (Runkle, 1987) with 1,000 replications.

\section{EMPIRICAL RESULTS}

\section{A. Data and Variable Sets for TVARs}

We use U.S. quarterly time series data over the period 1959:1-2001:4. The details of the data used in this paper are described in Appendix I. The switching index in period $t$ is the lagged ex post real interest rate defined as $r r_{t-1}=R_{t-1}-400\left(P_{t} / P_{t-1}-1\right)$, where $R_{t}$ and $P_{t}$ are the nominal interest rate and the price level, respectively, in period $t$. The three-month Treasury bill rate is used as the nominal interest rate. Inflation is measured on the basis of the GDP deflator.

The top panel of Figure 1 depicts the ex post real rate of return on three-month Treasury bills along with, for comparison, the ex ante real rate. The quarterly expected rate of inflation is interpolated from the semiannual inflation forecast from the Livingston Survey, and the ex ante real interest rate is defined as the three-month Treasury bill rate minus the expected inflation rate. The ex post real rate dipped in the 1970s as inflation rose, whereas the ex ante real rate also dipped but by a smaller amount - perhaps reflecting the fact that the survey inflation forecast was much smoother than actual inflation during that period of high and volatile inflation. The downward movement in inflation, together with financial deregulation, in the early 1980s may have led to a sharp rise in the real rate: the ex ante and the ex post rates show a common drift, which is not closely related to the inflation process. After the mid-1980s the movement in the real rate became rather steady, but the rate itself remained moderately high. The ex ante real rate is smoother than the ex post real rate but tends to overshoot before 1980, when inflation was high, and to somewhat undershoot afterward. Garcia and Perron (1996) suggest that three different regimes are associated with drifts in the real interest rate. Choi (2002) suggests that the real rate may vary with shifts in the inflation process and shows that the real rate is negatively correlated with inflation when inflation persistence, or inflation itself, is below a threshold. ${ }^{8}$

\footnotetext{
${ }^{8}$ Inflation persistence tends to be associated with inflation in the United States. Inflation was rather persistent in the late 1960s, and it was high and highly persistent after the 1973 oil shock. Volcker's anti-inflation policy kept inflation in check in 1982, and thereafter policy has consistently aimed at keeping inflation low (see Choi, 2002).
} 
Figure 1. Real Interest Rates, Debt-to-GDP Ratio, and Growth in Government Spending

A. Real interest rates

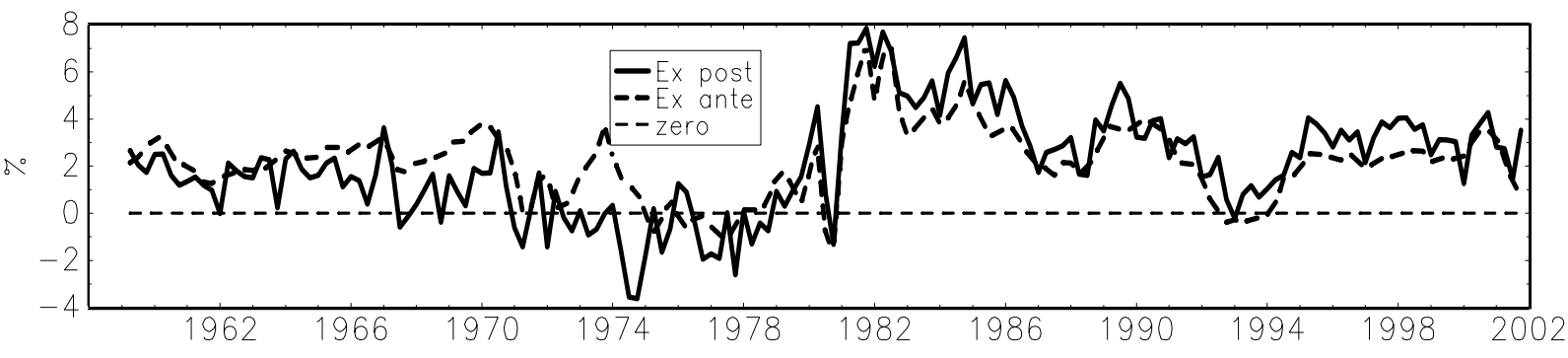

B. Debt-to-GDP ratio
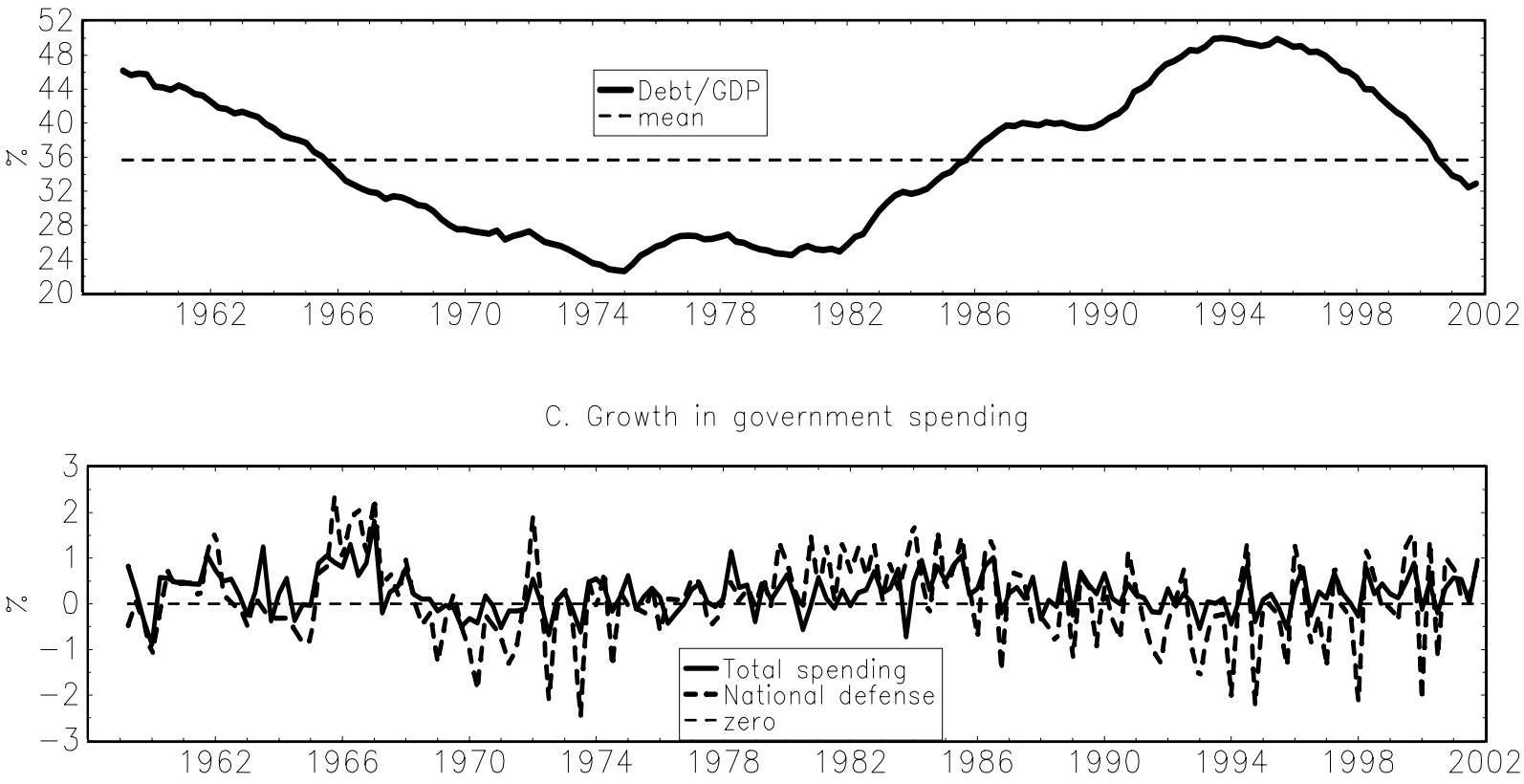

Notes: Real interest rates (first row) are measured by rates on three-month Treasury bills minus expected inflation from the Livingston Survey (ex ante rate) or minus actual inflation (ex post rate). The debt-output ratio (second row) is measured by nominal Federal government debt divided by nominal GDP. The growth rates of total real government spending and real national defense spending (last row) are in annualized percentage (see the appendix).

The middle panel of Figure 1 depicts the debt-output ratio, which is measured by nominal Federal government debt divided by nominal GDP. The ratio shows a different time-varying pattern from the real rate: the debt-output ratio exhibited a downward trend in the 1960s followed by an upward trend in the 1980s and the first half of the 1990s. ${ }^{9}$ The bottom panel shows growth in total government spending, measured by real government consumption expenditures and gross investment, and in national defense spending, measured by real national

\footnotetext{
${ }^{9}$ The regime classification according to the level of government debt (Sutherland, 1997; Perotti, 2002) is associated with the "accumulation" of government spending that has been financed by government bond issuance, reflecting the level of "fiscal stress" of the economy.
} 
defense consumption expenditures and gross investment. Government spending grew rather rapidly in the 1960s and the mid-1980s. Growth in national defense spending is highly correlated with (correlation coefficient $=0.70$ ) but more volatile than growth in total spending: it is high during periods of war (especially in the late 1960s, because of the Vietnam War) and moderately high in the 1980s (the period of the Carter-Reagan defense buildup); it is often negative in the 1970s and the 1990s, contributing to a downward trend in the ratio of national defense spending to total government spending.

We now construct the variable sets for TVARs. In model 1, the vector $\boldsymbol{Y}_{t}$ includes three variables to capture real economic activity, the growth rate of real government spending $\left(\Delta \ln G_{t}\right)$, the growth rate of real private spending $\left(\Delta \ln Z_{t}\right)$, and the growth rate of real GDP ( $\Delta \ln X_{t}$ ), and two variables associated with financing methods and costs, the growth rate of real government debt $\left(\Delta \ln D_{t}\right)$ and the change in the (nominal) interest rate $\left(\Delta R_{t}\right)$. Real private spending $\left(Z_{t}\right)$ is measured by either real private consumption $\left(C_{t}\right)$ or real private investment $\left(I_{t}\right)$. The interest rate is measured by the three-month Treasury bill rate. Thus, model 1 is given by

Model 1: TVAR with the ordering $\left\{\Delta \ln G_{t}, \Delta \ln D_{t}, \Delta \ln Z_{t}, \Delta \ln X_{t}, \Delta R_{t}\right\}$.

To account for money financing of government spending and for inflation, we also consider a model with monetary growth, inflation, and the interest rate as follows:

Model 2: TVAR with the ordering $\left\{\Delta \ln G_{t}, \Delta \ln M_{t}, \Delta \ln Z_{t}, \Delta \ln X_{t}, \Delta \ln P_{t}, R_{t}\right\}$,

where $\Delta \ln M_{t}$ and $\Delta \ln P_{t}$ are, respectively, the growth rate of money and inflation. ${ }^{10}$ The money stock is measured by the monetary base, and the price level by the GDP deflator. The (annualized) growth rate is measured by multiplying the log difference of a variable by 400 .

The periods of the low- and high-rate regimes may be partly associated with monetary policy: tighter monetary policy, which constrains the money financing of fiscal policy, may lead to increased interest rates, although not necessarily to a high level in the real rate (e.g., tight monetary policy in the 1970s; see Choi, 1999). In particular, tighter monetary policy calls for an increase in the real rate under the Taylor rule during the Volcker-Greenspan era but not during other periods (Clarida et al., 2000). To control for a channel through which the effectiveness of fiscal policy could be affected by monetary policy, we include changes in interest rates (model 1) and interest rates and money growth (model 2). In model 1, we use all variables in first difference, since we find that all level variables for the whole sample are non-stationary. ${ }^{11}$ In

\footnotetext{
${ }^{10}$ The law of motion of government debt can be written in a simple form as $D_{t+1}=A G_{t}^{\alpha} D_{t}^{\beta}$. This can be rewritten in a $\log$-differenced form, $\Delta \ln D_{t+1}=\alpha \Delta \ln G_{t}+\beta \Delta \ln D_{t}$, which can be extended to a more general form in a VAR.

${ }^{11}$ For the whole sample period, all variables in levels in model 1 are stationary, and Johansen's maximumeigenvalue test and trace test reject the null hypothesis of cointegration in model 1 when private spending is measured by consumption but not when it is measured by investment. For model 2, the growth of monetary base, and inflation have a unit root while the ex post real interest rate is stationary. We find mild evidence of cointegration for model 2 when private spending is measured by investment. (The results of unit root and cointegration tests are available from the authors upon request.) Estimating models in levels to account for the possible cointegration among level variables, however, does not affect our main results qualitatively.
} 
model 2, to account for the possibility that the interest rate can be cointegrated with inflation, we include the interest rate and inflation. ${ }^{12}$ We set the lag length at 2 for model 1 with investment growth and at 3 for other models: this lag length selection is based on the Akaike information criterion for the whole sample VAR.

The Choleski ordering that places government spending first is based on the identifying assumption that fiscal shocks have contemporaneous impacts on, but do not respond contemporaneously to, aggregate spending and other variables (Bernanke and Blinder, 1992; Christiano, Eichenbaum, and Evans, 1996). This assumption is likely to be a reasonable approximation, since government spending must be discussed and approved before it is implemented (Alesina and others, 2002) and reacts little to changes in macroeconomic conditions (Fatás and Mihov, 2003). ${ }^{13}$

\section{B. Tests for Threshold Effects}

\section{Linearity testing and number of regimes}

To begin with, we perform linearity testing to determine whether a threshold effect exists. If a single regime is rejected, we then determine whether there are two or three regimes, using Hansen's $(1999,2000)$ approach. In each equation the errors are assumed to be homoskedastic within a regime but heteroskedastic across regimes.

Table 1 reports the results of linearity testing for the four key variables along with inflation, assuming a single threshold as the alternative hypothesis. The test results tend to indicate that the null of linearity is rejected in favor of a single threshold: the likelihood-ratio test statistic for a threshold effect, $F_{1}$, is highly significant for the interest rate and inflation equations $(p<0.01$ for both), and mildly significant for the investment growth equation $(p<0.10)$ and the output growth equation $(p<0.15)$. The results, however, suggest weak or little evidence of a threshold effect in the consumption growth equation (especially in model 2, $p>0.40$ ). The least squares estimate of the threshold $\tau$ involves some degree of uncertainty, as indicated by a confidence interval ( 90 percent) that is not very tight and, in some cases, half-open, possibly owing to small sample size. The number of observations for the low- and the high-rate regimes, for example, in model 1 with consumption growth, is 47 and 120, respectively, classified by a threshold of 0.945 .

Although the results are not reported, the same testing procedure yielded no evidence of nonlinearity for the government spending growth equation $(p>0.30$ in most cases). In addition, we find little or weak evidence of nonlinearity for the government debt growth and money growth equations. The threshold estimate varies substantially both across models for the investment growth and output growth equations and across equations (the interest rate equation versus the others), suggesting the possibility of a double threshold. Since the $F_{1}$ statistic tends to

\footnotetext{
${ }^{12}$ We also estimate TVARs in levels to account for possible cointegrations among level variables but obtain qualitatively the same conclusion.

${ }^{13}$ Alesina and others (2002) note that, in the United States, the yearly budget is discussed and approved during the second half of the preceding year and that additional small fiscal measures are sometimes decided during the year, but most of the time they become effective by the end of the year. Fatás and Mihov (2003) suggest that spending is less prone to simultaneity problems in determining fiscal policy effects than the budget deficit is, since spending is not related to the current state of the economy whereas the budget deficit is largely affected by the cycle.
} 
Table 1. Tests for a Single Threshold and Threshold Estimates

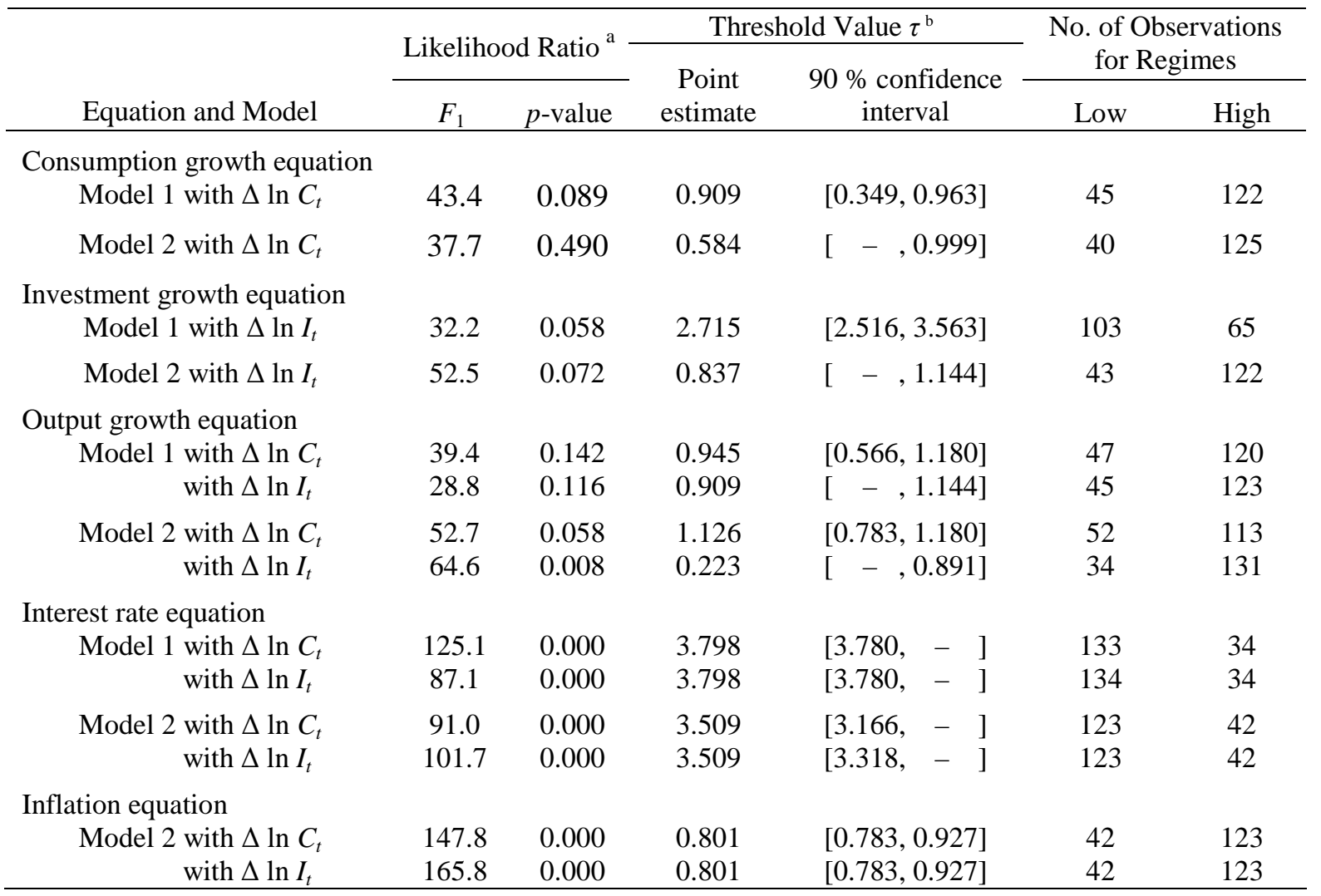

Notes: ${ }^{\mathrm{a}}$ The likelihood-ratio test statistic, $F_{1}$, is for the null hypothesis of no threshold against the alternative hypothesis of single threshold, following Hansen $(1999,2000)$. The asymptotic $p$-values are reported in parentheses. The number of simulation replications for each grid was set at $J=1,000$. The lag length is set at 2 for model 1 with investment growth and at 3 for other models, based on the Akaike information criterion for the whole sample VAR.

b The grid set: $\Gamma=\left\{100\right.$ grids evenly dividing the range from the $20^{\text {th }}$ to the $80^{\text {th }}$ percentile of the switching index $\}$. The 90 $\%$ confidence interval for $\tau$ is computed using the likelihood-ratio statistic following Hansen (1999).

reject the null of no threshold effect for the investment growth, output growth (model 2), interest rate, and inflation equations, we proceed with a further test to discriminate between one and two thresholds for these equations.

Table 2 reports the likelihood-ratio test statistic of one versus two thresholds, $F_{2}$, and the refinement estimator (Bai, 1997; Hansen, 1999) of the double threshold $\left(\tau_{L}^{r}, \tau_{U}^{r}\right)$ for the investment growth, output growth, interest rate, and inflation equations in each model. The $F_{2}$ statistic rejects the null of one threshold in favor of two thresholds at the 5 percent level for the interest rate and inflation equations in both models. However, the $F_{2}$ statistic is insignificant for the investment equation in both models and largely insignificant for the output equation except that it is significant at the 5 percent for model 2 with $\Delta \ln C_{t}$. The 90 percent confidence intervals for two thresholds are calculated based on the refinement estimator. Again, the confidence intervals of the threshold estimates are not very tight and, in several cases, half-open, possibly owing to small sample size. Since the $F_{2}$ statistic indicates strong evidence of a double threshold for the interest rate and inflation equations, we hereafter consider a three-regime model. 
Table 2. Tests for a Double Threshold and Threshold Estimates

\begin{tabular}{|c|c|c|c|c|c|c|c|c|c|}
\hline \multirow[b]{3}{*}{ Equation and model } & & & \multicolumn{4}{|c|}{ Threshold Value $\tau^{\mathrm{b}}$} & & & \\
\hline & \multicolumn{2}{|c|}{ Likelihood Ratio $^{\text {a }}$} & \multicolumn{2}{|c|}{ Lower bound $\left(\tau_{L}^{r}\right)$} & \multicolumn{2}{|c|}{ Upper bound $\left(\tau_{U}^{r}\right)$} & \multicolumn{3}{|c|}{ No. of Observations } \\
\hline & $F_{2}$ & $\begin{array}{c}\text { Asymptotic } \\
p \text {-value }\end{array}$ & $\begin{array}{c}\text { Point } \\
\text { estimate }\end{array}$ & $\begin{array}{c}90 \% \text { confidence } \\
\text { interval }\end{array}$ & $\begin{array}{c}\text { Point } \\
\text { estimate }\end{array}$ & $\begin{array}{c}90 \% \text { confidence } \\
\text { interval }\end{array}$ & $\begin{array}{l}\text { Low- } \\
\text { rate } \\
\text { regime }\end{array}$ & $\begin{array}{l}\text { High- } \\
\text { rate } \\
\text { regime }\end{array}$ & $\begin{array}{l}\text { Moderate- } \\
\text { rate } \\
\text { regime }\end{array}$ \\
\hline \multicolumn{10}{|c|}{ Investment growth equation } \\
\hline Model 1 with $\Delta \ln I_{t}$ & 22.7 & 0.275 & 0.681 & {$[-, 1.111]$} & 2.737 & {$[2.582,3.599]$} & 41 & 62 & 65 \\
\hline Model 2 with $\Delta \ln I_{t}$ & 45.2 & 0.299 & 0.359 & {$[0.345,0.808]$} & 2.710 & {$[2.297,3.320]$} & 37 & 63 & 65 \\
\hline \multicolumn{10}{|l|}{ Output growth equation } \\
\hline Model 1 with $\Delta \ln C_{t}$ & 42.5 & 0.116 & 1.113 & {$[0.902,1.136]$} & 2.317 & {$[-, 2.508]$} & 52 & 39 & 76 \\
\hline with $\Delta \ln I_{t}$ & 21.1 & 0.324 & 0.909 & {$[0.247,1.116]$} & 3.798 & {$[3.478,-]$} & 47 & 87 & 34 \\
\hline Model 2 with $\Delta \ln C_{t}$ & 64.9 & 0.035 & 1.125 & {$[0.340,0.808]$} & 3.217 & {$[1.548,1.594]$} & 52 & 63 & 50 \\
\hline with $\Delta \ln I_{t}$ & 50.4 & 0.184 & 0.360 & {$[0.337,0.886]$} & 3.660 & {$[3.498,-\quad]$} & 37 & 91 & 37 \\
\hline \multicolumn{10}{|l|}{ Interest rate equation } \\
\hline Model 1 with $\Delta \ln C_{t}$ & 55.8 & 0.025 & 1.376 & {$[0.776,2.362]$} & 3.798 & {$[3.783,-\quad]$} & 59 & 74 & 34 \\
\hline with $\Delta \ln I_{t}$ & 33.5 & 0.051 & 0.896 & {$[0.820,1.208]$} & 3.798 & {$[3.776,-]$} & 44 & 90 & 34 \\
\hline Model 2 with $\Delta \ln C_{t}$ & 145.9 & 0.000 & 0.186 & {$[-, 0.309]$} & 3.813 & {$[3.790$} & 32 & 98 & 33 \\
\hline with $\Delta \ln I_{t}$ & 129.3 & 0.000 & 0.186 & {$[-, 0.274]$} & 3.813 & {$[3.416$} & 32 & 98 & 33 \\
\hline \multicolumn{10}{|l|}{ Inflation equation } \\
\hline Model 2 with $\Delta \ln C_{t}$ & 100.6 & 0.035 & 0.845 & {$[0.779,0.911]$} & 3.486 & {$[3.233,3.486]$} & 43 & 78 & 42 \\
\hline with $\Delta \ln I_{t}$ & 102.4 & 0.025 & 0.186 & {$[-, 0.568]$} & 3.396 & {$[3.233,3.486]$} & 32 & 86 & 45 \\
\hline
\end{tabular}

Notes: ${ }^{a}$ The likelihood-ratio test statistic, $F_{2}$, is for the null hypothesis of single threshold against the alternative hypothesis of double threshold, following Hansen (1999). The asymptotic $p$-values are reported in parentheses. The number of simulation replications for each grid was set at $J=1,000$. The lag length is set at 2 for model 1 with investment growth and at 3 for other models.

b The threshold parameters are based on the refinement estimator (Bai, 1997; Hansen 1999). The grid set: $\Gamma=\{50$ grids for the refinement estimator, given the firstor the second-stage threshold estimate\}. 


\section{Specification tests for asymmetry across regimes}

Table 3 summarizes the specification test results for individual equations in TVARs with a double threshold. Following Hansen (1996), we compute three test statistics: SupW, AveW, and $\operatorname{Exp} W$. All three indicate that linearity is rejected against a double threshold at the 1 percent level in all cases for the interest rate and inflation equations and at the 5 percent level or less for the consumption growth and investment growth equations. Linearity in the output growth equation is rejected for model 1 by all the statistics at the 10 percent level and for model 2 at the 1 percent level. We also performed a specification test for parameter constancy across given subsamples as if the threshold estimate $\tau$ (reported in the notes to Figures 3 and 4) were the true value, as in Durlauf and Johnson (1995) and Choi (1999, 2002). The last three columns of the table provide evidence against parameter constancy across the subsamples in most cases except for the output growth equations in model 1 with investment growth $(p>0.10)$. Although the results are not reported, we found no evidence of asymmetry in government spending growth (test statistics were insignificant at the 10 percent level in all models). Taken together, these results give credence to threshold effects in interest rates, and inflation and (sometimes mild) support for such effects in consumption growth, investment growth, and output growth.

Overall the symmetry test results provide evidence on the coefficient shifts in most of the key regressions, consistent with the proposed switching mechanism. An increase in government spending affects not only aggregate demand directly but also consumption and investment through, for example, its impact on interest rates. In addition, it involves the negative impact from the Ricardian effect through anticipated increases in future tax liabilities. Weak evidence of asymmetry in consumption (as seen in Table 1) may reflect shifts in one parameter being offset by changes in others, leaving the coefficients largely intact. However, asymmetry in other equations in the system can feed into the dynamic properties of consumption through the lagged values of other variables in the system. Thus, and more importantly, we need to explore whether the dynamic responses of the economy to a government spending shock exhibit asymmetry across regimes.

Before examining the different impacts of a spending shock across regimes, we look at how the regime type and the relation between real rates and output growth evolve over time. The top panel of Figure 2 displays the regime type index based on the estimated thresholds for model 1 with investment growth-it consists of the low- and moderate-rate regimes until 1980 (with one exception in 1967:1) but the high- and moderate-rate regimes after 1980 (with one exception in 1993:1). The middle panel of Figure 2 depicts output growth (quarter to quarter, annualized) along with real interest rates: output growth is seen to be the more volatile series (especially before the mid-1980s). The bottom panel of Figure 2 shows that the regime mean of real interest rates is negatively related to that of output growth: the mean of the real rate is -0.97 percent for the low-rate regime, 1.92 percent for the moderate-rate regime, and 4.94 percent for the high-rate regime; means for output growth are $3.89,3.45$, and 2.59 percent, respectively. 
Table 3. Specification Tests for Asymmetry in TVARs

\begin{tabular}{|c|c|c|c|c|c|c|c|c|c|}
\hline \multirow[b]{3}{*}{ Equation and Model } & \multicolumn{9}{|c|}{ Type of Test Statistics } \\
\hline & \multicolumn{6}{|c|}{ Across Regimes $^{\mathrm{a}}$} & \multicolumn{3}{|c|}{ Across Subsamples ${ }^{\mathrm{b}}$} \\
\hline & SupW & $p$-value & $\operatorname{Exp} W$ & $p$-value & AveW & $p$-value & $\chi^{2}$ & $d f$ & $p$-value \\
\hline \multicolumn{10}{|c|}{ Consumption growth equation } \\
\hline Model 1 with $\Delta \ln C_{t}$ & 61.0 & 0.017 & 51.0 & 0.008 & 27.9 & 0.012 & 52.2 & 32 & 0.013 \\
\hline Model 2 with $\Delta \ln C_{t}$ & 84.6 & 0.000 & 60.9 & 0.006 & 37.1 & 0.000 & 60.7 & 38 & 0.011 \\
\hline \multicolumn{10}{|c|}{ Investment growth equation } \\
\hline Model 1 with $\Delta \ln I_{t}$ & 47.9 & 0.017 & 39.6 & 0.007 & 21.2 & 0.013 & 39.4 & 22 & 0.013 \\
\hline Model 2 with $\Delta \ln I_{t}$ & 80.3 & 0.001 & 60.6 & 0.007 & 36.2 & 0.001 & 62.4 & 38 & 0.008 \\
\hline \multicolumn{10}{|l|}{ Output growth equation } \\
\hline Model 1 with $\Delta \ln C_{t}$ & 58.6 & 0.026 & 43.6 & 0.052 & 25.7 & 0.032 & 56.2 & 32 & 0.005 \\
\hline with $\Delta \ln I_{t}$ & 43.0 & 0.056 & 33.0 & 0.049 & 18.1 & 0.054 & 30.2 & 22 & 0.114 \\
\hline Model 2 with $\Delta \ln C_{t}$ & 90.9 & 0.000 & 65.0 & 0.002 & 40.5 & 0.000 & 67.7 & 38 & 0.002 \\
\hline with $\Delta \ln I_{t}$ & 89.4 & 0.000 & 65.2 & 0.001 & 40.1 & 0.000 & 50.3 & 38 & 0.006 \\
\hline \multicolumn{10}{|l|}{ Interest rate equation } \\
\hline Model 1 with $\Delta \ln C_{t}$ & 117.4 & 0.000 & 87.9 & 0.000 & 53.7 & 0.000 & 76.8 & 32 & 0.000 \\
\hline with $\Delta \ln I_{t}$ & 89.8 & 0.000 & 75.3 & 0.000 & 41.0 & 0.000 & 74.3 & 22 & 0.000 \\
\hline Model 2 with $\Delta \ln C_{t}$ & 110.0 & 0.000 & 81.3 & 0.000 & 50.8 & 0.000 & 100.4 & 38 & 0.000 \\
\hline with $\Delta \ln I_{t}$ & 118.8 & 0.000 & 93.0 & 0.001 & 54.8 & 0.000 & 110.2 & 38 & 0.000 \\
\hline \multicolumn{10}{|l|}{ Inflation equation } \\
\hline Model 2 with $\Delta \ln C_{t}$ & 216.7 & 0.000 & 173.5 & 0.000 & 102.4 & 0.000 & 154.1 & 38 & 0.000 \\
\hline with $\Delta \ln I_{t}$ & 210.5 & 0.000 & 182.7 & 0.001 & 101.6 & 0.000 & 197.4 & 38 & 0.000 \\
\hline
\end{tabular}

asymptotic $p$-values are reported in parentheses. The number of simulation replications for each grid was set at $J=1,000$. The set of grid points for $\left(\tau_{L}, \tau_{U}\right): \Gamma=\{$ all the grids at grid search with 40 grids for each threshold $\}$ ( $\# \Gamma=1,600)$.

${ }^{\mathrm{b}}$ The result of the Wald tests of the null that the coefficients of the indicated equation are constant across the indicated subsamples grouped by $\hat{\tau}$, which is reported in the corresponding notes of Figures 3 and 4 . The test statistics follow the chi-square distributions with degrees of freedom $(d f)$ in parentheses under the null. The $d f$ for the interest equation in a TVAR equals $2(1+$ number of variables $\times$ number of lags). The $p$-values are reported in parentheses. 
Figure 2. Regime Type Index, Real Interest Rates, and Output Growth

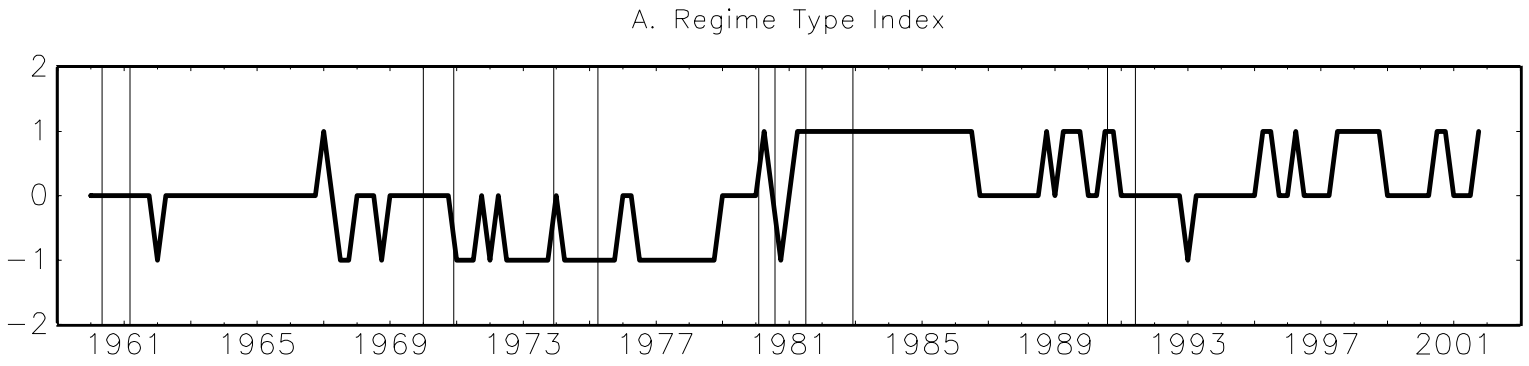

B. Output Growth and Real Interest Rate

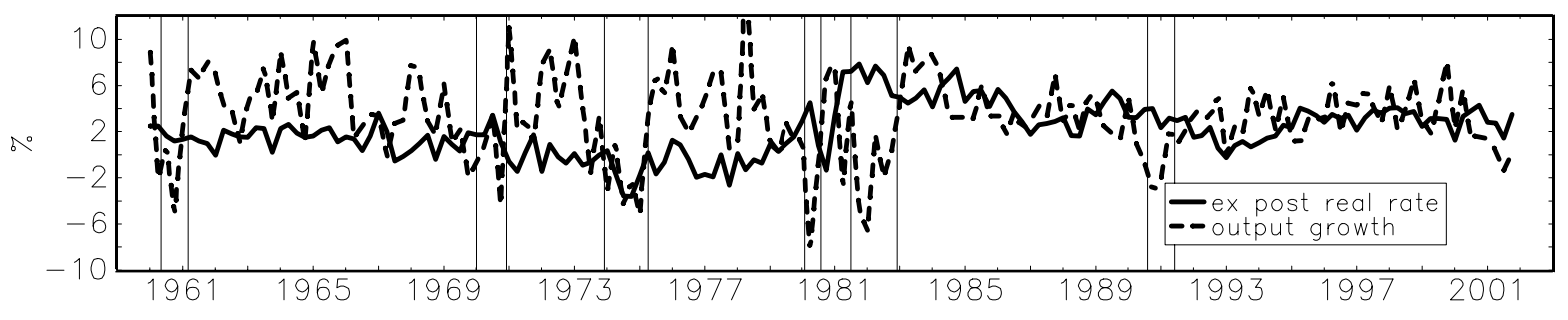

C. Regime Mean of Output Growth and Real Interest Rate

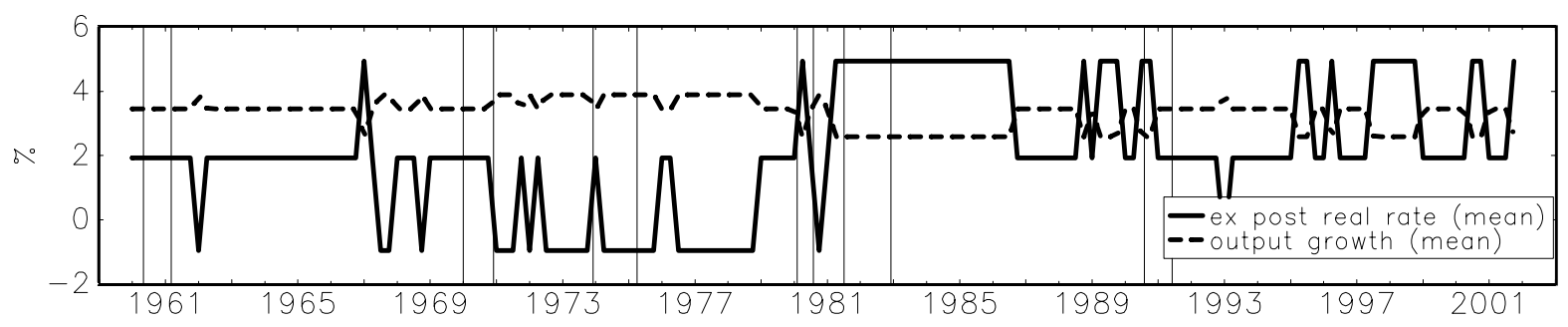

Notes: Regime type in panel A is determined on the basis of the estimated thresholds for model 1 with investment growth (see notes to Figure 3): low-rate regime, -1; moderate-rate regime, 0; high-rate regime, 1 . The regime mean in panel $\mathrm{C}$ is the subsample mean of a variable for the corresponding regime. Vertical lines indicate NBER business cycle peaks and troughs.

Real interest rates are negatively associated with output growth in terms of the regime mean, and the regime-mean difference of real rates from one to next regime is more than 2 percent, much greater than that of output growth. So abstracting from average output growth in measuring the switching index seems a reasonable approximation. ${ }^{14}$ In addition, business cycle recessions have no systemic relations with the classified regimes (top panel of Figure 2), although they are clearly negatively associated with output growth (middle panel). Lastly, the relationship between real rates and output growth accounts for the debt-output ratio transition in the middle panel of Figure 1: for example, the dominance of the low-rate regime before 1980characterized by periods when, on average, real interest rates were lower than output growth rates-is associated with a downward trend in the debt-output ratio.

\footnotetext{
${ }^{14}$ As a result, the use of an alternative switching index, the real interest minus the regime-mean output growth, will not affect the result, while it requires an iterative estimation to obtain the regime-mean output growth.
} 


\section{TVAR Models and Impulse Responses to a Government Spending Shock}

We consider a positive shock of 1 percentage point to the rate of government spending growth (annualized) and its dynamic effects on the variables in TVARs. Our impulse-response analysis focuses on the case where the real rate is around its mean under each regime, so that small changes in the real rate after the shock do not entail a shift to another regime.

The response of government spending growth itself to such a shock shows a similar pattern across regimes (results not shown): the only difference, if any, takes the form of greater persistence under the low-rate regime than under the others. Therefore we focus here on whether the impulse responses of real activity (consumption, investment, and output) to the shock confirm empirically the anticipated larger impact of government spending when that spending creates less future liabilities than when it creates more future liabilities. We also examine the associated responses of interest rates, inflation, and financing methods.

\section{Responses of real activity}

Figures 3 and 4 depict the responses of either consumption or investment growth and output growth in models 1-2. The shock initially increases consumption growth (top row of each figure). In contrast with the responses for the whole sample (far right graph in each row), consumption responses differ across regimes. In models 1 and 2 (top row in each figure), the initial impacts on consumption growth are stronger under the low-rate regime than under the moderate-rate regime. However, consumption growth initially increases under the high-rate regime as well, perhaps because smaller responses of the real interest rate under that regime temper the adverse impact of the Ricardian effect.

The investment growth (third row in each figure) responses of the whole sample, when significant, are negative for all models_-perhaps attributable to crowding-out effects. In contrast, the initial impacts of the spending shock on investment growth are significantly positive under the low-rate regime but (significantly or insignificantly) negative under other regimes. This asymmetry may be explained as follows. The productivity-enhancing effect of higher spending induces higher investment. When real rates are sufficiently high, however, a possible future increase in taxes has two opposing effects on investment: the prospect of higher corporate taxes discourages investment, but higher income taxes decrease consumption (through a wealth effect), increase labor supply, and thus increase investment. Under the low-rate regime, investment growth initially increases (a dominating, productivity-enhancing effect) but then declines after a few quarters as interest rates rise (a crowding-out effect). Under the high-rate regime, the spending shock has no boosting effect on investment growth and, if anything, results in lower investment growth (a negative net effect of future taxes on investment).

Output responses (second and fourth rows in Figures 3 and 4) are initially positive in most cases, but this is more pronounced under the low-rate regime than other regimes. This finding is consistent with the responses of consumption and investment growth under each regime. Under the low-rate regime of model 2, output growth responses show a trough around the fifth quarter, with significantly negative values, reflecting a $\mathrm{V}$-shape in the investment growth responses. The moderate-rate regime somewhat mimics the whole sample that entail an initial positive response. 


\section{Figure 3. Impulse Responses of Real Activity in Model 1}

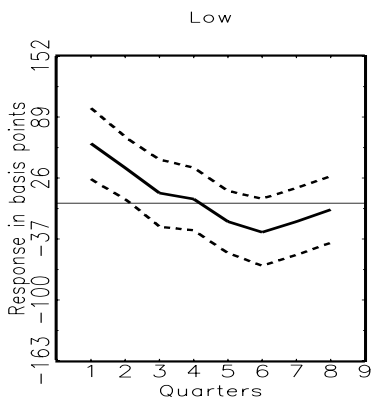

A. With consumption growth, response of $\Delta \ln C_{t}$
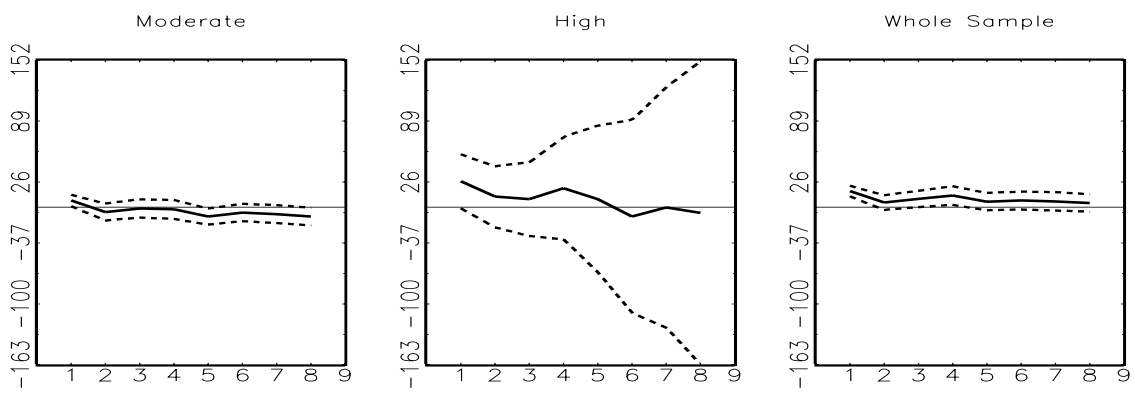

B. With consumption growth, response of $\Delta \ln Y_{t}$
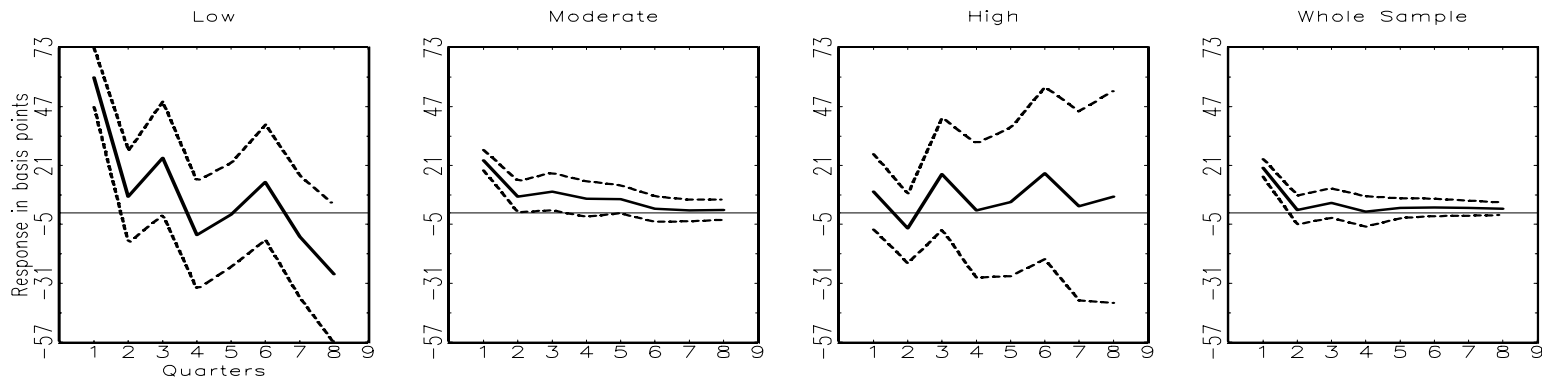

C. With investment growth, response of $\Delta \ln I_{t}$
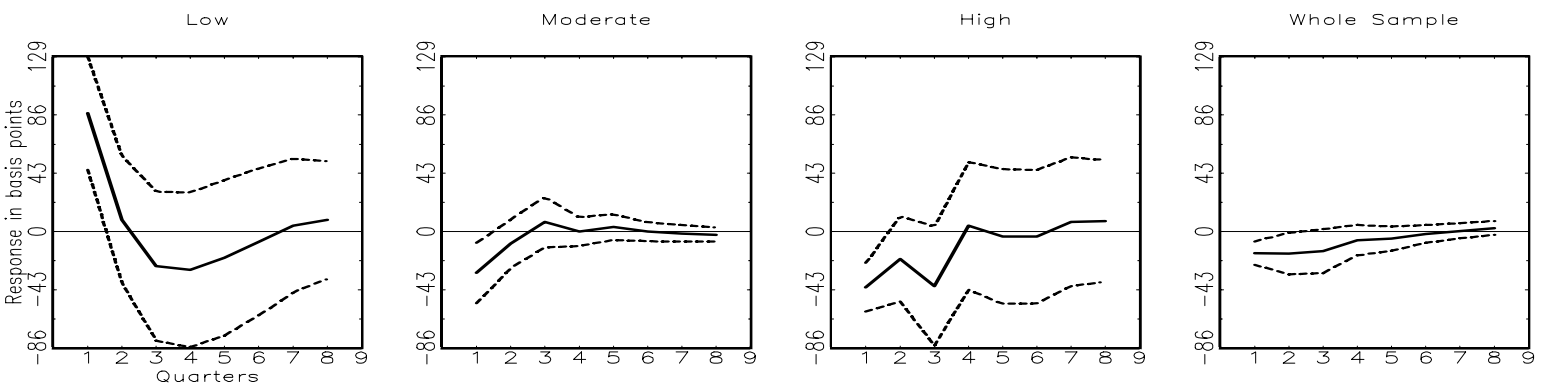

D. With investment growth, response of $\Delta \ln Y_{t}$
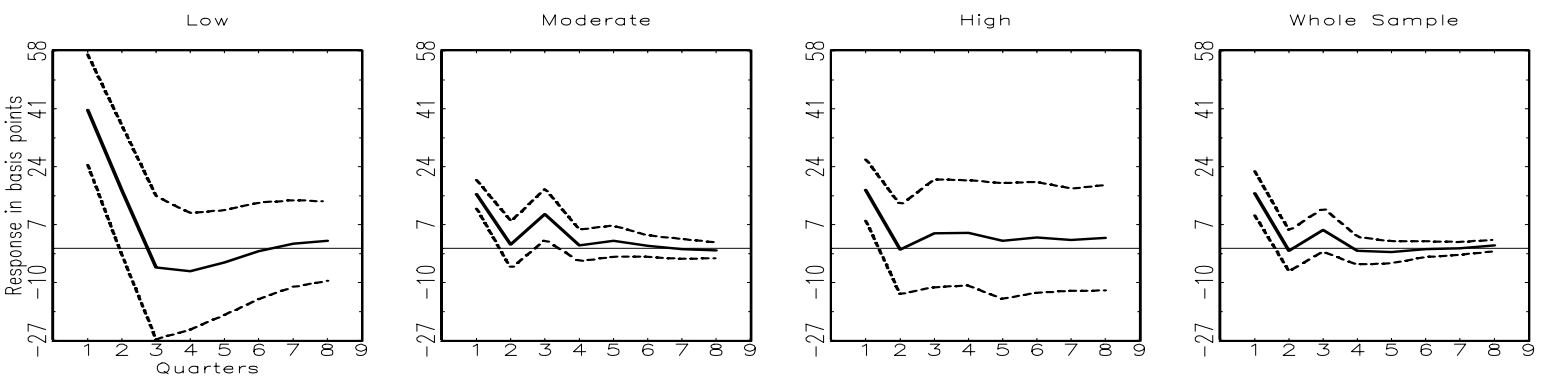

Notes: For model 1 with consumption growth, estimated thresholds, $\left(\tau_{L}, \tau_{H}\right)$, are $(0.358,3.643)$, and the number of sample observations for low, moderate, and high regimes are $(37,93,37)$. For model 1 with investment growth, estimated thresholds, $\left(\tau_{L}, \tau_{H}\right)$, are $(0.223,3.485)$, and the number of sample observations for low, moderate, and high regimes are $(33,93,42)$. Dashed lines are one-standard error bands. 
Figure 4. Impulse Responses of Real Activity in Model 2

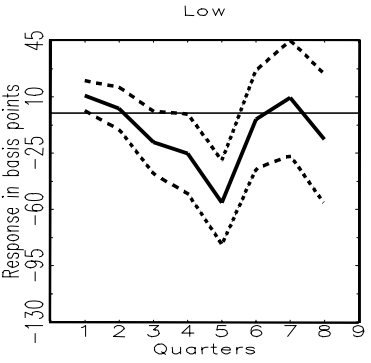

A. With consumption growth, response of $\Delta \ln C_{t}$
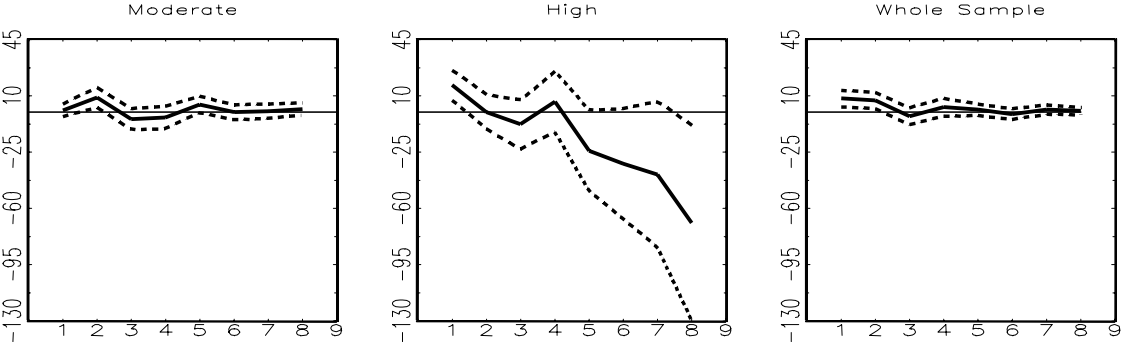

B. With consumption growth, response of $\Delta \ln Y_{t}$
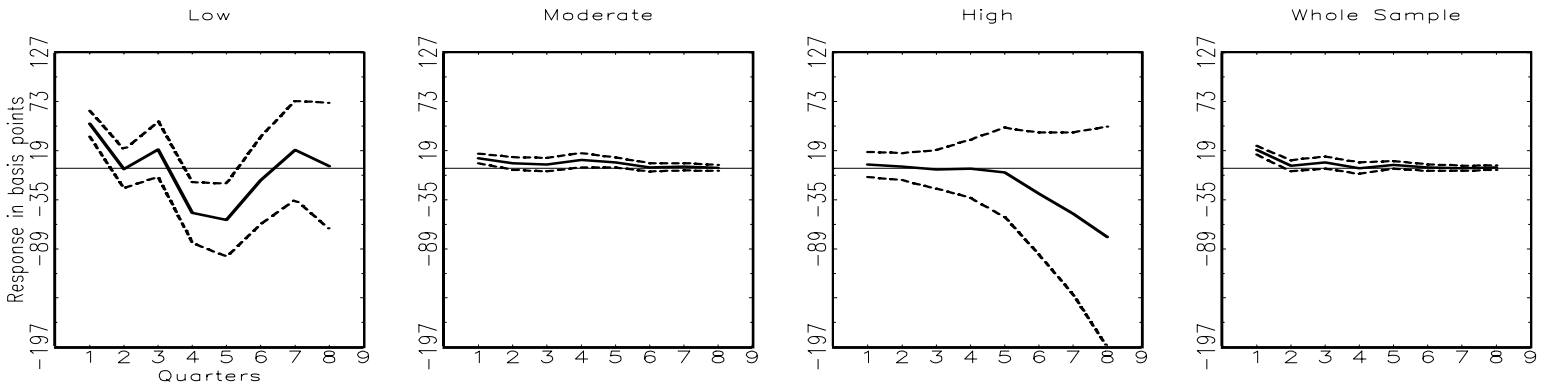

C. With investment growth, response of $\Delta \ln I_{t}$
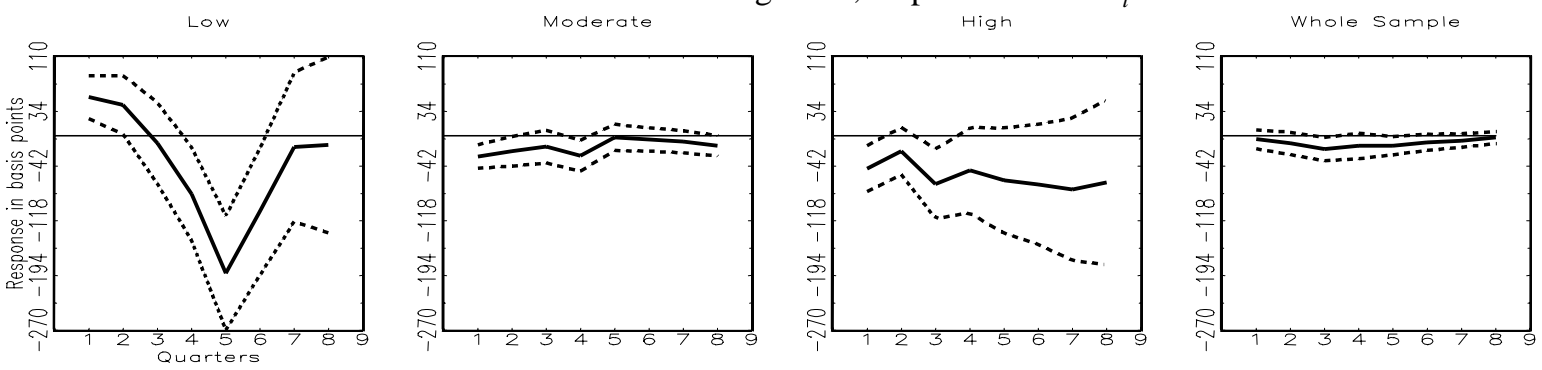

D. With investment growth, response of $\Delta \ln Y_{t}$
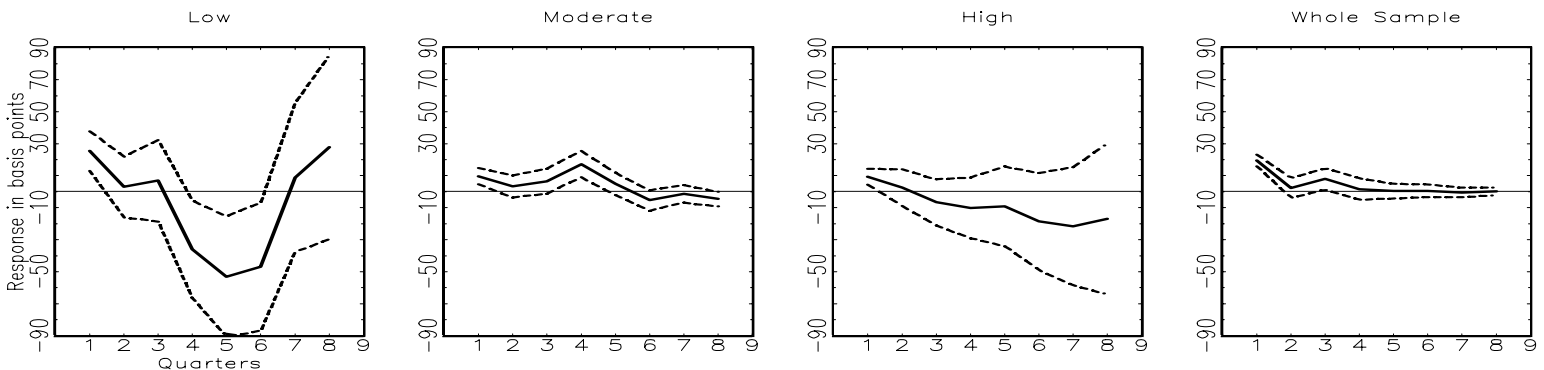

Notes: For model 2 with consumption growth, estimated thresholds, $\left(\tau_{L}, \tau_{H}\right)$, are $(0.257,3.705)$, and the number of sample observations for low, moderate, and high regimes are $(34,97,36)$. For model 2 with investment growth, estimated thresholds, $\left(\tau_{L}, \tau_{H}\right)$, are $(0.257,3.395)$, and the number of sample observations for low, moderate, and high regimes are $(34,88,45)$. Dashed lines are one-standard error bands. 
Table 4. Output Growth Responses

\begin{tabular}{|c|c|c|c|c|c|c|c|c|}
\hline \multirow{2}{*}{$\begin{array}{l}\text { Quarters } \\
\text { After } \\
\text { Shock }\end{array}$} & \multicolumn{4}{|c|}{ Model 1} & \multicolumn{4}{|c|}{ Model 2} \\
\hline & Low & Moderate & High & Whole & Low & Moderate & High & Whole \\
\hline & \multicolumn{4}{|c|}{ With $\Delta \ln C_{t}$} & \multicolumn{4}{|c|}{ With $\Delta \ln C_{t}$} \\
\hline $1-2$ & $\begin{array}{l}33.4 \\
(9.4)\end{array}$ & $\begin{array}{l}15.2 \\
(5.5)\end{array}$ & $\begin{array}{c}1.2 \\
(10.5)\end{array}$ & $\begin{array}{l}10.6 \\
(3.9)\end{array}$ & $\begin{array}{c}23.9 \\
(11.2)\end{array}$ & $\begin{array}{c}7.9 \\
(4.6)\end{array}$ & $\begin{array}{c}2.9 \\
(119)\end{array}$ & $\begin{array}{l}11.3 \\
(4.9)\end{array}$ \\
\hline $2-4$ & 7.2 & 7.8 & 9.1 & 2.6 & -14.2 & 6.2 & -1.1 & 3.1 \\
\hline \multirow[b]{2}{*}{$5-8$} & (14.5) & (5.6) & $(21.0)$ & (4.9) & (22.7) & (5.4) & (24.7) & $(4.8)$ \\
\hline & $\begin{array}{c}-6.2 \\
(10.4)\end{array}$ & $\begin{array}{c}2.6 \\
(4.4)\end{array}$ & $\begin{array}{c}8.1 \\
(33.6)\end{array}$ & $\begin{array}{c}2.2 \\
(3.0)\end{array}$ & $\begin{array}{l}-12.1 \\
(18.1)\end{array}$ & $\begin{array}{c}2.3 \\
(3.1)\end{array}$ & $\begin{array}{c}-39.7 \\
(79.7)\end{array}$ & $\begin{array}{c}1.1 \\
(2.8)\end{array}$ \\
\hline & \multicolumn{4}{|c|}{ With $\Delta \ln I_{t}$} & \multicolumn{4}{|c|}{ With $\Delta \ln I_{t}$} \\
\hline $1-2$ & $\begin{array}{c}28.8 \\
(15.5)\end{array}$ & $\begin{array}{c}8.5 \\
(3.9)\end{array}$ & $\begin{array}{c}8.4 \\
(8.5)\end{array}$ & $\begin{array}{c}7.7 \\
(3.5)\end{array}$ & $\begin{array}{c}14.1 \\
(12.3)\end{array}$ & $\begin{array}{c}6.5 \\
(4.6)\end{array}$ & $\begin{array}{c}6.0 \\
(6.6)\end{array}$ & $\begin{array}{l}10.8 \\
(4.4)\end{array}$ \\
\hline $2-4$ & $\begin{array}{l}-6.2 \\
(166\end{array}$ & $\begin{array}{c}5.5 \\
(50)\end{array}$ & 4.5 & $\begin{array}{c}2.4 \\
(48)\end{array}$ & $\begin{array}{r}-14.6 \\
(20.3)\end{array}$ & $\begin{array}{l}11.8 \\
(588)\end{array}$ & -8.4 & 4.8 \\
\hline $5-8$ & $\begin{array}{c}-0.4 \\
(10.8)\end{array}$ & $\begin{array}{c}0.5 \\
(2.5)\end{array}$ & $\begin{array}{c}2.7 \\
(15.3)\end{array}$ & $\begin{array}{l}-0.1 \\
(1.9)\end{array}$ & $\begin{array}{c}-15.9 \\
(17.7)\end{array}$ & $\begin{array}{c}-1.6 \\
(3.8)\end{array}$ & $\begin{array}{c}-16.6 \\
(33.0)\end{array}$ & $\begin{array}{c}0.1 \\
(2.7)\end{array}$ \\
\hline
\end{tabular}

Notes: (i) The impulse responses (in basis points) were calculated for the first-half year (1-2 quarters), the second-half (3-4 quarters), and the second year (5-8 quarters) for the low-rate, moderate-rate, and high-rate regimes as well as for the whole sample. The top (bottom) panel pertains to the responses of output growth to a government spending shock in models with the consumption (investment) growth variable. Standard errors (in parentheses) are calculated from the bootstrapping with 1,000 replications. (ii) The estimated grids for TVARs are reported in the corresponding notes to Figures 3 and 4.

Table 4 reports point estimates and standard errors of averages over time of the output growth responses. Under the low-rate regime, the response in the first half-year is mostly significant except for model 2 with investment growth: for example, in model 1 with consumption growth, the response is significantly positive ( 33.4 basis points) and about three times as large as that in the whole sample (10.6 basis points). Under the moderate-rate regime, the first-half-year response is in the range of 6 to 15 basis points but significant only in model 1. Under the high-rate regime, the output growth response is statistically insignificant in all cases: for example, the first-half-year response is in the range of 1.2 to 8.4 basis points and insignificant.

The whole sample analysis in Figures 3 and 4 shows initial positive responses of consumption growth and output growth and initial negative responses of investment growth, findings that are consistent with earlier empirical findings that government spending shocks have a positive effect on consumption and output (Blanchard and Perotti, 2002) and a strong negative effect on investment (Blanchard and Perotti, 2002; Alesina and others, 2002). ${ }^{15}$ In contrast, the TVAR analysis shows initial favorable effects on the growth of investment as well as the growth of consumption and output under the low-rate regime, but less favorable or (significantly or insignificantly) adverse effects under other regimes. This asymmetry indicates that expansionary government spending is more conducive to increased real activity in the short run when real rates are low than when they are high. Although no direct comparisons with existing studies are

\footnotetext{
${ }^{15}$ Blanchard and Perotti (2002) estimate structural VAR models, which contain tax, government spending, output, and an individual GDP component (such as consumption or investment) in a level form controlling for trends, for the post-1960 U.S. data. Alesina and others (2002), using a simple structural model for a panel of industrial countries, find that government spending shocks lead to a decrease in the investment-GDP ratio.
} 
possible, this result reconciles Perotti's (2002) finding that the effects of fiscal policy on output and its components have become substantially weaker over the last 20 years for the United States (and other industrial countries), because the post-1980 period was largely one of high- and moderate-rate regimes, whereas the pre-1980 period was largely one of low- and moderate-rate regimes (bottom panel of Figure 2). Also, considering that the low-rate regime tends to be associated with periods of high inflation (top panel of Figure 1), the stronger effect of government spending on aggregate demand with lower real rates is in accord with Koelln, Rush, and Waldo's (1996) finding from cross-country data that the government spending multiplier increases with inflation if inflation is sufficiently high.

\section{Responses of interest rates and inflation}

The top row of Figure 5 shows the responses of nominal interest rates to the government spending shock in model 2. The nominal interest rate shows greater responses under the low-rate regime than under the other regimes. Nominal interest rate responses after two to three quarters of the shock are significantly positive under the low-rate regime. However, smaller positive or little responses under the moderate-rate regime and (significantly or insignificantly) negative under the high-rate regime and for the whole sample are shown.

Conventional macroeconomic theory suggests that expansionary government spending raises interest rates, a consequence that one would expect if aggregate demand rises (an income effect). But why does the shock have a positive impact on the nominal interest rate only under the lowrate regime? The initial positive responses of output growth under the low-rate regime, which exert upward pressures on interest rates, partly answer this question. Nonetheless, a thorough answer requires a further look at the responses of inflation and real interest rates.

The bottom two rows of Figure 5 depict inflation responses to the shock under different regimes. Significant positive inflation responses are seen under the low-rate regime with a lag, which is largely attributable to upward pressures from aggregate demand, occurring with a lag. In contrast, under the high-rate regime and for the whole sample no or much smaller positive responses of inflation are seen. ${ }^{16}$ These asymmetric responses of inflation are consistent with positive responses of nominal interest rates under the low-rate regime and non-positive responses under the high-rate regime (as implied by a Fisher effect). The inflation responses are also consistent with the output growth responses under different regimes, since the shock appears to contribute to aggregate demand only under the low-rate regime in most cases.

Non-positive responses of nominal rates under the high- and the moderate-rate regimes may partly reflect that the Mankiw (1987) effect of government spending on real rates is regimedependent. The Mankiw effect will be stronger under the high-rate regime, since government spending is more costly to finance and thus induces stronger negative impacts on consumption (through the Ricardian effects) and real rates when real rates are high than when they are low.

\footnotetext{
${ }^{16}$ Commodity price inflation can be included in model 2 to cope with the "price puzzle" - the finding that a monetary tightening leads to a rising rather than falling price level (Leeper, Sims, and Zha, 1996; Christiano, Eichenbaum, and Evans, 1996). We find that the inclusion of commodity price inflation does not alter our main results.
} 
Figure 5. Impulse Responses of Nominal Interest Rates and Inflation in Model 2

A. With consumption growth, response of nominal interest rates
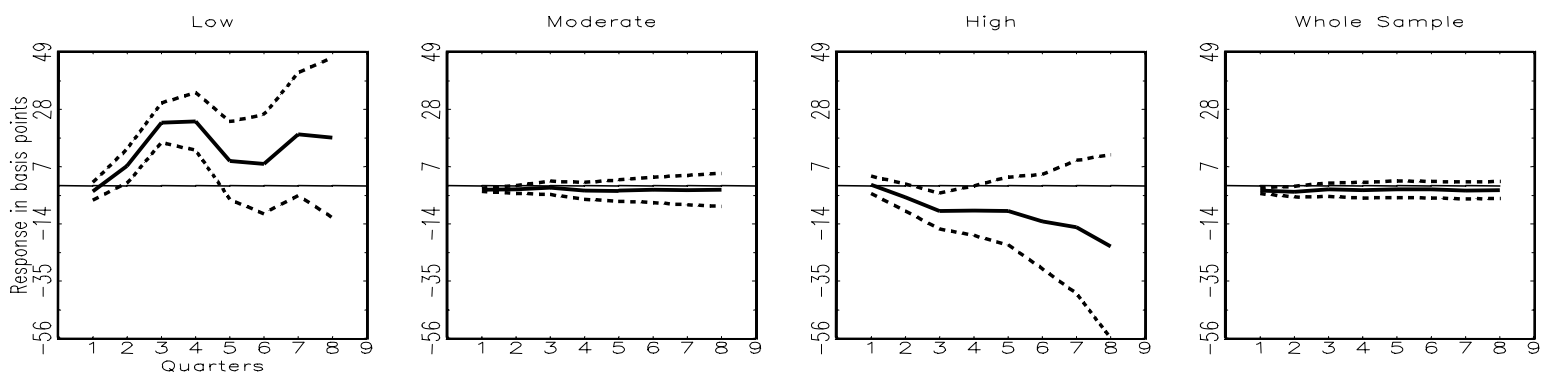

B. With investment growth, response of nominal interest rates
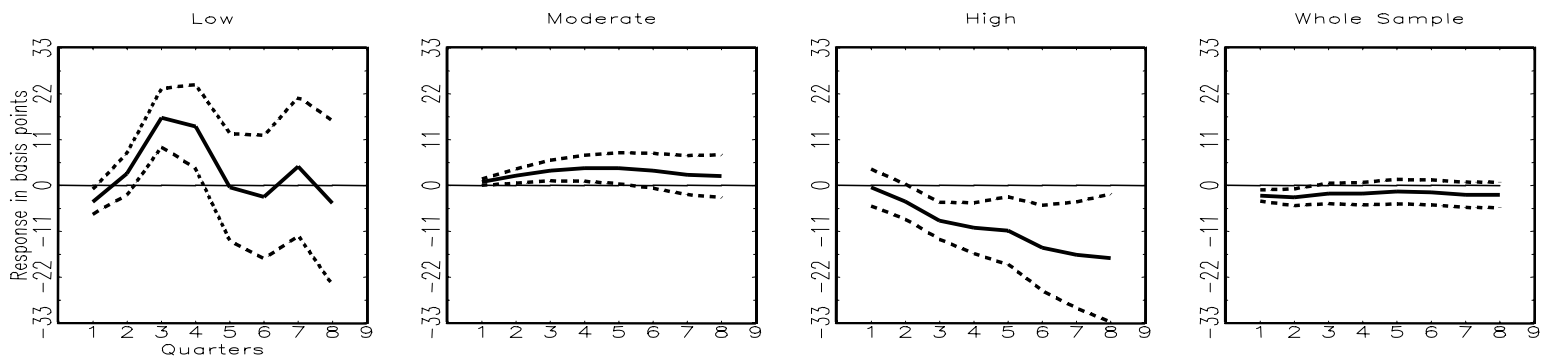

C. With consumption growth, response of inflation
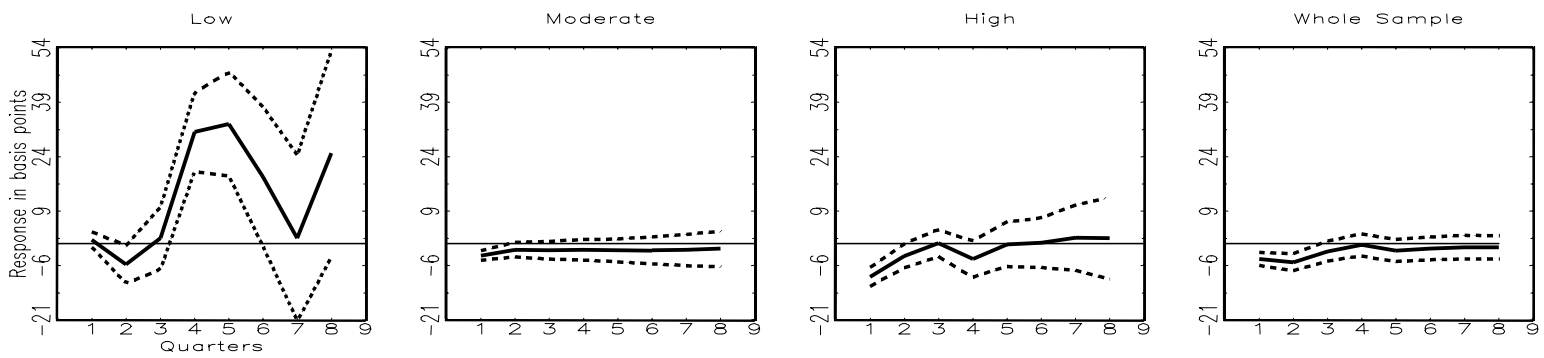

D. With investment growth, response of inflation
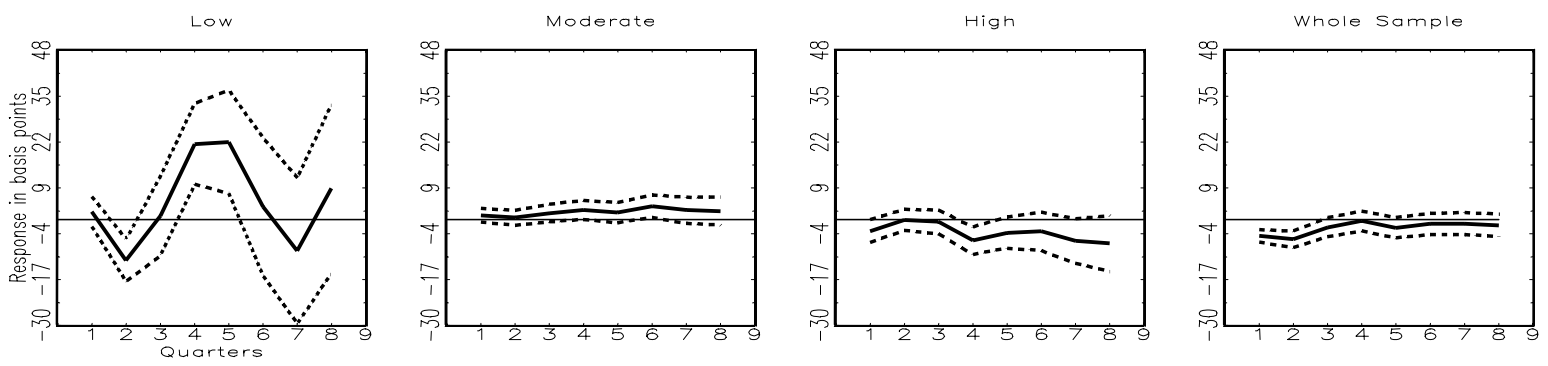

Notes: For model 2 with consumption growth (first and third rows), estimated thresholds, $\left(\tau_{L}, \tau_{H}\right)$, are $(0.257$, 3.705), and the number of sample observations for low, moderate, and high regimes are (34, 97 36). For model 2 with investment growth (second and last rows), estimated thresholds, $\left(\tau_{L}, \tau_{H}\right)$, are $(0.257,3.395)$, and the number of sample observations for low, moderate, and high regimes are $(34,88,45)$. Dashed lines are one-standard error bands. 
To test our conjecture that the Mankiw effect is partly responsible for the negative response of nominal rates to an increase in government spending, we look at real rate responses. We put the ex post real rate, $r r_{t}$, measured by the period- $t$ nominal interest rate minus the period- $t+1$ inflation rate in place of $R_{t}$ in model 2, to account for the effect of government spending on interest rates through money growth and inflation responses. We refer to this modified version as model 2'. Figure 6 shows real rate responses in this model. The response of the real rate is much greater under the low-rate regime than under the other regimes, suggesting a regime-dependent Mankiw effect. Under the low-rate regime, insignificant initial responses are followed by significant positive responses, perhaps because the effect on real rates of the associated, lagged increase in aggregate demand dominates the Mankiw effect. Around four or five quarters after the shock, the positive responses of real rates are associated with negative responses in consumption and investment. Conversely, under the moderate- and the high-rate regimes, insignificant or negative responses are shown. The whole sample shows largely insignificant impacts of government spending on real rates.

To the extent that a positive shock to government spending leads to budget deficits given existing tax rates, the non-positive responses of interest rates in the whole sample and under the high- and moderate-rate regimes are consistent with earlier findings that budget deficits have little effect on prices (Dwyer, 1982) and on real and nominal rates of interest (Evans, 1987), supported by the Ricardian effects. In contrast, the positive responses of interest rates under the low-rate regime reconcile the Keynesian prediction.

Figure 6. Impulse Responses of Real Interest Rates in Model 2'

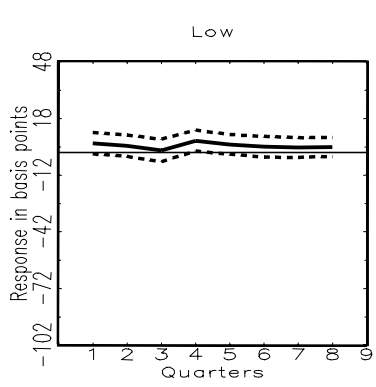

A. With consumption growth
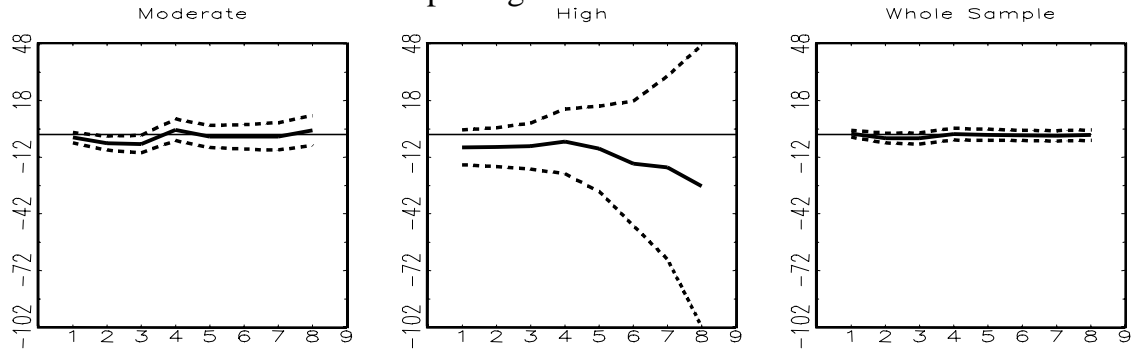

B. With investment growth
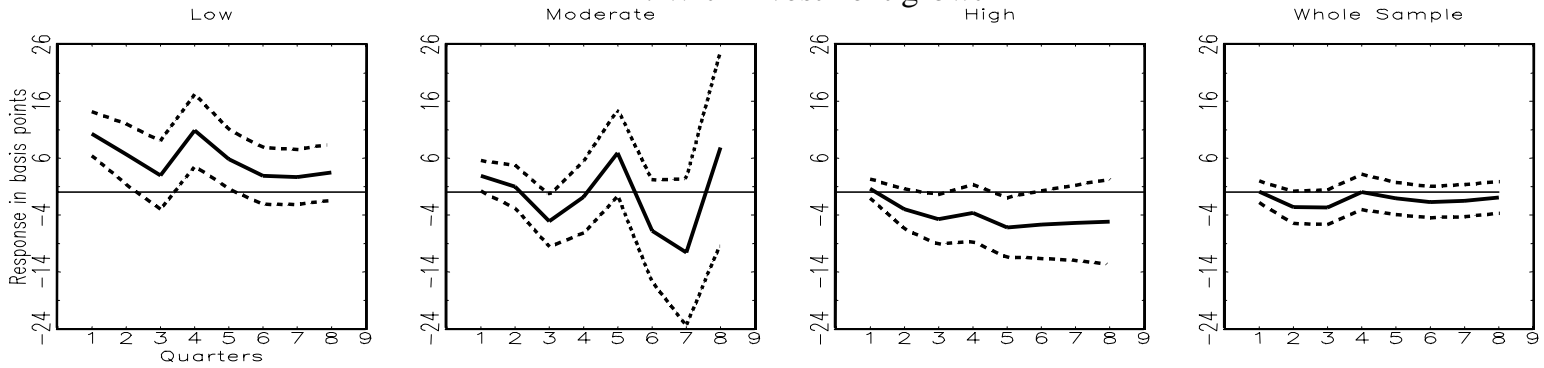

Notes: For model $2^{\prime}$ with consumption growth, estimated thresholds, $\left(\tau_{L}, \tau_{H}\right)$, are $(1.398,3.813)$, and the number of sample observations for low, moderate, and high regimes are $(60,70,34)$. For model $2^{\prime}$ with investment growth, estimated thresholds, $\left(\tau_{L}, \tau_{H}\right)$, are $(1.363,2.641)$, and the number of sample observations for low, moderate, and high regimes are $(59,40,65)$. Dashed lines are one-standard error bands. 
The low-rate regime tends to be associated with periods of high inflation, and the high-rate regime with periods of low inflation. Given this, our finding of positive responses of inflation only under the low-rate regime reconciles Fischer, Sahay, and Végh's (2000) finding of a significant positive association between inflation and the fiscal balance for countries and periods with high inflation but not for low-inflation countries and low-inflation periods in usually highinflation countries. Also, the stronger effect of government spending on inflation with lower real rates and thus higher inflation is consistent with Ball, Mankiw, and Romer's (1988) contention that the sensitivity of inflation to aggregate demand shocks increases with inflation because economic agents adjust more frequently to keep up with inflation.

\section{Responses of financing methods}

Figure 7 depicts the responses of government debt growth (in model 1) and money growth (in model 2) to the government spending shock. Under each regime, additional government spending is initially financed by debt (first and third rows of the figure). The initial positive responses of both financing methods under the moderate-rate regime are similar to those in the whole sample analysis. Under the low-rate regime, debt finance is significantly positive initially but becomes small or insignificant as real returns on bonds, whose level was initially low, rise (see Figure 6).

Substitution between government debt issuance and money creation in the face of different real interest rates reflects attempts to reduce the cost of government spending. It is remarkable that money growth (second and fourth rows) rises significantly after a short lag, showing a hump shape, under the high-rate regime but not under the low-rate regime, whereas it shows only a brief initial increase under the moderate-rate regime. This finding indicates that the financing of government spending relies on money creation only when the cost of debt financing is relatively high. Under the high-rate regime, the positive response of money growth dampens as the real rate, whose level was initially high, declines. Under the low-rate regime, the V-shaped responses of money growth seem to mirror the V-shaped responses in investment and consumption growth.

\section{Robustness Checks and Discussion}

We find that the use of alternative variable sets (the real money stock M1 in place of the monetary base; real interest rates in place of nominal interest rates) and different ordering in TVARs (for example, placing money growth after output growth) do not affect the main results qualitatively. Also, alternative lag lengths yield qualitatively similar results.

As an alterative switching index, we used the ex ante real interest rate. The results are similar with respect to the existence of a double threshold, but overall we find less pronounced asymmetries in the dynamic responses to a government spending shock-perhaps because the overshooting in the ex ante real rate before 1980 results in an obtuse discrimination of observations between the low- and the moderate-rate regime (top panel of Figure 1). Table 5 reports the point estimates and standard errors of the average output growth response over time with this switching index. A pattern similar to that in Table 4 is observed, although asymmetric effects are often less pronounced. Using another alternative switching index measured by the 
Figure 7. Impulse Responses of Financing Methods in Models 1 and 2

A. With consumption growth, responses of $\Delta \ln D_{t}$, Model 1
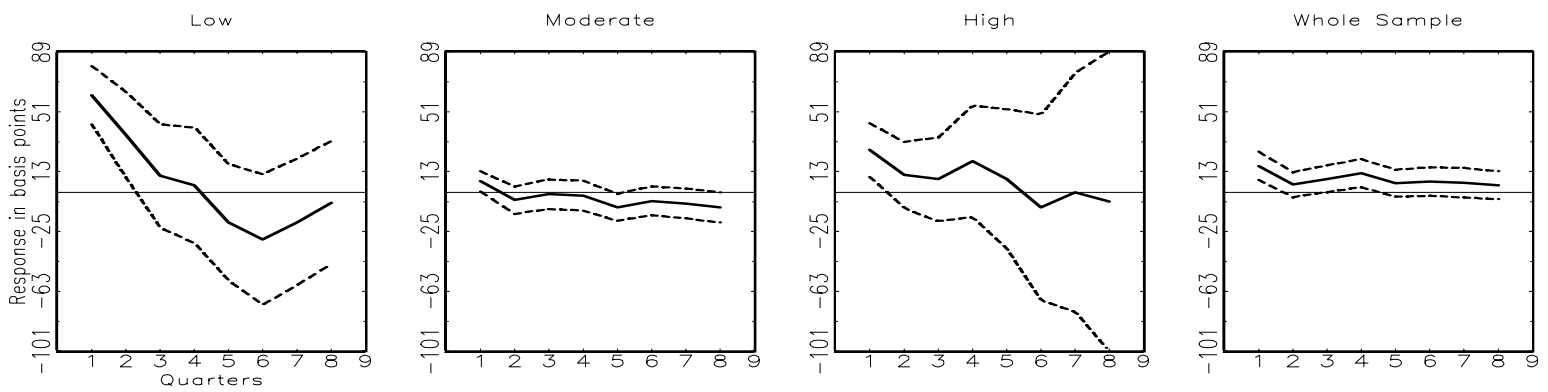

B. With consumption growth, responses of $\Delta \ln M_{t}$, Model 2
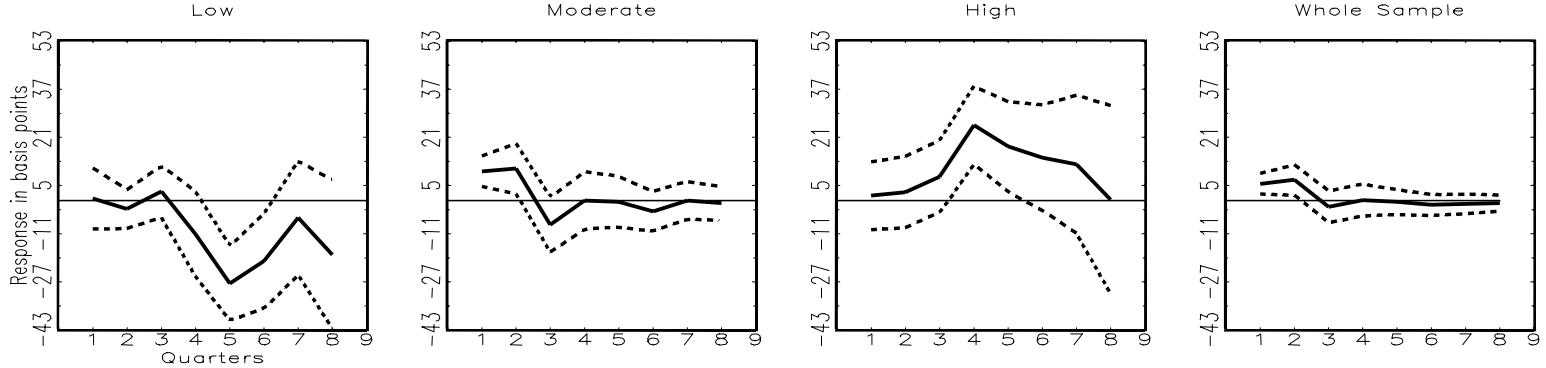

C. With investment growth, responses of $\Delta \ln D_{t}$, Model 1
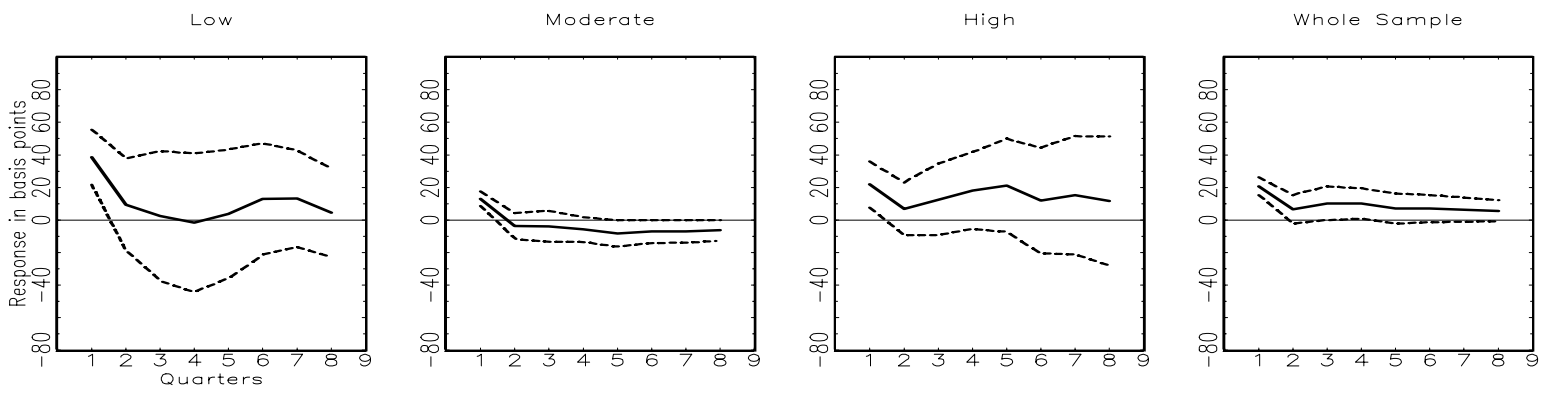

D. With investment growth, responses of $\Delta \ln M_{t}$, Model 2
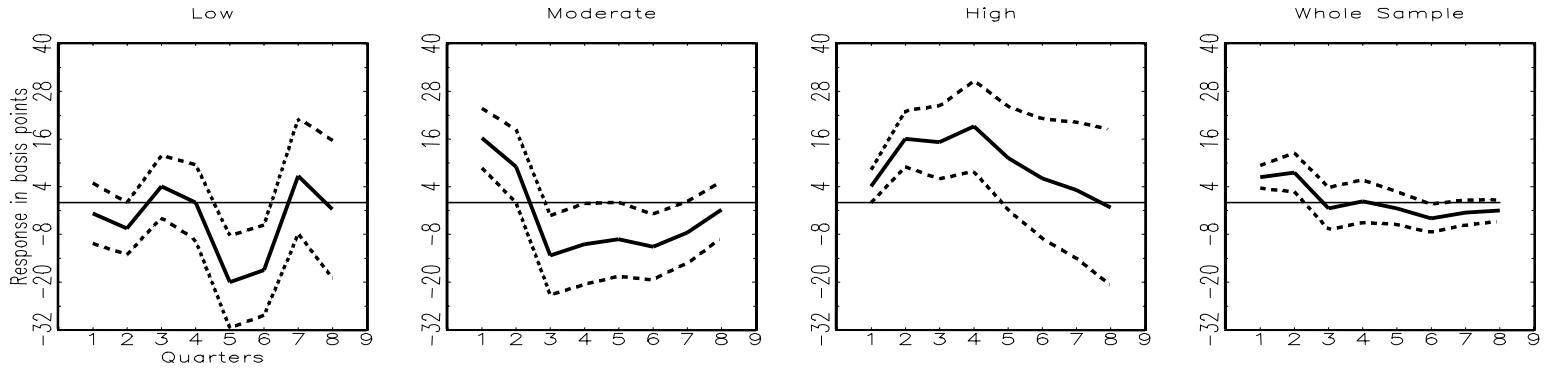

Notes: For model 1 with consumption growth (first row) and investment growth (third row), respectively, estimated thresholds, $\left(\tau_{L}, \tau_{H}\right)$, are $(0.358,3.643)$ and $(0.223,3.485)$, and the number of sample observations for low, moderate, and high regimes are $(37,93,37)$ and $(33,93,42)$. For model 2 with consumption growth (second row) and investment growth (last row), respectively, estimated thresholds, $\left(\tau_{L}, \tau_{H}\right)$, are $(0.257,3.705)$ and $(0.257$, $3.395)$, and the number of sample observations for low, moderate, and high regimes are $(34,97,36)$ and $(34,88,45)$. Dashed lines are one-standard error bands. 
government debt-output ratio, we found no evidence on asymmetry in consumption (or investment) and output growth equations and no evidence on asymmetric effects of government spending, although linearity testing suggests a single threshold for the interest rate and inflation equations. As noted earlier, the gradient, rather than the level, of the debt-output ratio is associated with the real interest rate. Hence, no evidence of asymmetric fiscal policy effects in terms of the debt-output ratio suggests that the dynamics of debt-integral factor of forming agents' expectations for future fiscal consolidation-is more important for assessing debt sustainability than the current status of debt.

The composition of expenditure may matter (Kormendi, 1983; Aschauer, 1989; Barro and Sala-ì-Martin, 1992; Tanzi and Zee, 1997). For example, an increase in spending on government wages and salaries will have less favorable impacts on output than equivalent expenditure on goods and services and capital projects. Also, a shock to defense spending may have a different impact on the economy than a shock to spending elsewhere in the budget. ${ }^{17}$ However, we consider total government spending rather than expenditure composition, emphasizing the implication of the financing cost of government spending for future tax liabilities as a whole: it is difficult to take into account the implications of any individual expenditure component for the economy's tax liabilities because higher spending on any individual component could be offset by lower spending on others. Thus, using national defense spending as a measure of fiscal policy has limitations for our purpose. Nonetheless, we use this measure of fiscal policy for comparison and find that linearity testing supports threshold effects in TVARs. Compared with a shock to total government spending, a shock to national defense spending shows similar but less marked asymmetric effects across regimes and tends to have a greater crowding-out effect on consumption and investment irrespective of the regime (results not shown).

Our impulse-response analysis assumes no communication across regimes. This assumption remains robust as a good approximation, because a 1-percentage point shock does not have much of an effect on the real rate: the effect is only about 10 basis points at its peak or trough, as Figure 6 shows. Thus, the current regime at the median value of real rates is expected to prevail after the shock - the cumulative response of the real rate after eight quarters is less than 80 basis points, and so the switching index does not hit threshold values. Nonetheless, one may consider a more general case where a government spending shock affects the real rate enough to cause switching back and forth across regimes. For example, suppose government spending rises in the low-rate regime. Economic agents would anticipate a small rise in financing costs, and thus the crowding-out effects would be small, but in fact there is some probability of switching to a higher-rate regime. ${ }^{18}$ In general, however, the (conditional and nonlinear) responses depend not only on the level of real rates (initial conditions) but also on the size of the shock, rendering any summary of expected responses intractable.

\footnotetext{
${ }^{17}$ Kormendi (1983) finds from U.S. data that defense spending is in between government investment and government consumption in term of the size of crowding-out effect on private consumption. Evans and Karras (1998), using cross-country data analysis, suggest that private consumption and non-military government spending are substitutes, whereas private consumption and military spending are complements.

${ }^{18}$ To allow for shifts to other regimes at the margin, one may consider the estimation averages over the actual histories of real rates conditional on each regime, given a fixed size of shocks. This approach will somewhat smooth out differences across regimes but will not affect our results qualitatively, given that the moderate-rate regime, as a middle ground in the characteristics of responses, buffers a transition from one extreme regime to the other extreme unless the shock is extremely large.
} 
Table 5. Output Growth Responses with Ex Ante Real Rates as Switching Index

\begin{tabular}{|c|c|c|c|c|c|c|c|c|}
\hline \multirow{2}{*}{$\begin{array}{l}\text { Quarters } \\
\text { After } \\
\text { Shock }\end{array}$} & \multicolumn{4}{|c|}{ Model 1} & \multicolumn{4}{|c|}{ Model 2} \\
\hline & Low & Moderate & High & Whole & Low & Moderate & High & Whole \\
\hline & \multicolumn{4}{|c|}{ With $\Delta \ln C_{t}$} & \multicolumn{4}{|c|}{ With $\triangle \ln C_{t}$} \\
\hline \multirow[t]{2}{*}{$1-2$} & 23.2 & -5.4 & 8.4 & 10.6 & 31.7 & 5.3 & 8.2 & 11.3 \\
\hline & $(7.8)$ & $(10.4)$ & $(13.7)$ & (3.9) & $(12.9)$ & $(6.3)$ & $(6.1)$ & (4.9) \\
\hline \multirow[t]{2}{*}{$2-4$} & 2.6 & -3.3 & 14.9 & 2.6 & -12.8 & 0.3 & 6.0 & 3.1 \\
\hline & (11.3) & (9.8) & (14.6) & $(4.9)$ & $(20.2)$ & $(6.0)$ & (13.1) & $(4.8)$ \\
\hline \multirow[t]{2}{*}{ 5-8 } & 9.7 & 2.7 & 7.3 & 2.2 & 1.2 & -1.5 & -10.2 & 1.1 \\
\hline & $(9.0)$ & (5.7) & $(15.9)$ & (3.0) & $(13.5)$ & $(4.5)$ & $(32.8)$ & $(2.8)$ \\
\hline & \multicolumn{4}{|c|}{ With $\Delta \ln I_{t}$} & \multicolumn{4}{|c|}{ With $\Delta \ln I_{t}$} \\
\hline \multirow[t]{2}{*}{$1-2$} & 26.2 & -1.1 & 1.2 & 7.7 & 31.8 & -7.0 & 7.8 & 10.8 \\
\hline & (9.4) & (6.8) & (6.3) & (3.5) & $(15.6)$ & $(5.5)$ & (7.2) & (4.4) \\
\hline \multirow[t]{2}{*}{$2-4$} & -1.1 & -3.3 & 12.6 & 2.4 & -14.3 & -1.3 & 12.4 & 4.8 \\
\hline & $(10.0)$ & $(7.2)$ & $(11.4)$ & $(4.8)$ & $(21.2)$ & $(7.2)$ & $(10.0)$ & $(4.8)$ \\
\hline \multirow[t]{2}{*}{$5-8$} & 1.3 & -1.0 & 5.6 & -0.1 & 2.5 & -2.7 & 4.3 & 0.1 \\
\hline & $(4.3)$ & (3.5) & (11.5) & $(1.9)$ & $(17.3)$ & $(6.5)$ & $(10.8)$ & $(2.7)$ \\
\hline
\end{tabular}

Notes: (i) The ex ante real rate is measured as the 3-month Treasury bill rate minus expected inflation. To obtain a proxy for expected inflation, the 6-months-ahead forecast of inflation is taken from the Livingston Survey and interpolated at quarterly frequency. (ii) See note (i) to Table 4. (iii) The lag lengths chosen for models are the same as those for models with the ex post real rate as switching index (Table 4). (iv) For model 1 with consumption growth and that with investment growth, estimated thresholds, $\left(\tau_{L}, \tau_{H}\right)$, are commonly $(1.713,2.592)$, and the number of sample observations for low, moderate, and high regimes are $(54,53,61)$ and $(54,53,60)$ respectively. For model 2 with consumption growth and that with investment growth, estimated thresholds, $\left(\tau_{L}, \tau_{H}\right)$, are $(1.157,2.943)$ and $(1.157,2.592)$ respectively, and the number of sample observations for low, moderate, and high regimes are $(37,83,47)$ and $(37,70,60)$ respectively.

We find evidence that, in times of low real interest rates, a fiscal expansion is conducive to boosting economic activity in the short run. ${ }^{19}$ However, such a stimulating effect dies out fast if fiscal policy continues to be expansionary enough to deteriorate the economic environment by raising real interest rates and accelerating debt accumulation, switching to a high-rate regime. In particular, an expansionary fiscal policy could be less than effective for an economy with persistent government deficits and pervasively high real interest rates. Since perfect foresight during the entire time horizon of interest is often far from reality, agents can update their assessment of debt sustainability based on the evolving status determined by the financial cost of fiscal policy. Thus, no perpetual benign effect of fiscal policy is warranted for an economy, even if it starts with the low-rate regime-fiscal austerity fosters a foundation for the efficacy of fiscal policy in times of need. Further, fiscal policy entails a trade-off between volatility and efficacy because an aggressive fiscal policy induces macroeconomic volatility, which in turn lowers economic growth, as shown in Fatás and Mihov (2003).

\footnotetext{
${ }^{19}$ When nominal interest rates are very low, a fiscal expansion—before deflation brings rising real interest ratesmay prove conducive to boosting economic activity in the short run. In contrast, monetary expansion through the typical channels of open market operations may not be effective because cutting interest rates close to zero renders money little different from government securities and makes frictions in financial markets to outweigh the benefits of marginally cheaper money (see Koenig and Dolmas, 2003).
} 


\section{CONCLUSION}

Earlier studies have looked for nonlinear effects of fiscal policy on the basis of different characteristics of the fiscal impetus or of consumers' expectations about future fiscal adjustment to achieve government debt sustainability. Little evidence, however, has been provided on the dependence of the efficacy of fiscal policy on the financing cost of government spending. This paper provides new empirical evidence on the relative effectiveness of fiscal policy at different levels of real interest rates. It shows that government spending has a significant positive shortrun impact on aggregate spending at low real rates but not much of an impact at relatively high real rates.

Additional findings on asymmetric effects of fiscal policy are noteworthy. First, government spending raises inflation and nominal interest rates, owing to higher aggregate demand, only when real interest rates are relatively low. Second, at low real interest rates, the effect of increased government spending on real interest rates is positive; and, at high real interest rates, it can be negative. Third, government spending induces debt issuance at low real interest rates and money creation at high real interest rates, indicating that substitution between debt issuance and money creation depends on the financing cost of government spending.

We interpret the new evidence on the asymmetric effects of fiscal policy on economic activity as suggesting that fiscal policy is likely to be more conducive to short-run growth when real interest rates are low. However, a ballooning government debt with persistent, expansionary government spending can be perceived as constraining fiscal policy-fiscal austerity thus may form a stronger foundation for the efficacy of fiscal policy in times of need. 


\section{Data Sources and the Description of the Variables}

We use the U.S. quarterly series, obtained from Federal Reserve Economic Data (FRED) at the website of the Federal Reserve Bank of St. Louis, in our analysis. Variable definitions and FRED code names are as follows: $X=$ real GDP, chained 1996 dollars (GDPC1); nominal GDP (GDP); $P=$ GDP deflator (=GDP/GDPC1); $G=$ real government consumption expenditures and gross investment, chained 1996 dollars (GCEC1); real national defense spending $=$ nominal national defense consumption expenditures and gross investment (FDEFX) divided by the GDP deflator; $C=$ real personal consumption expenditure, chained 1996 dollars (PCECC96); $I=$ real fixed private domestic investment, chained 1996 dollars (FPIC1); $D=$ nominal federal government debt (defined below) divided by GDP deflator; $M=$ the Federal Reserve Board of Governors' adjusted monetary base (BOGAMBSL); money stock M1 (M1SL); and $R=$ the threemonth Treasury bill rate, percent per annum (TB3MS). The data available at monthly frequency from the source are averaged to obtain quarterly observations. The nominal federal government debt is taken from the IMF's International Financial Statistics and seasonally adjusted (by X12).

The growth rate of a variable $x$ in annual percentage is defined as: $\Delta \ln x_{t}=400 \cdot \ln \left(x_{t} / x_{t-1}\right)$. The lagged ex post real interest rate is defined as: $r r_{t-1}=R_{t-1}-400 \cdot\left(P_{t} / P_{t-1}-1\right)$. The lagged ex ante real interest rate is measured by $R_{t-1}$ minus the expected inflation rate for period $t$, for which the six-months-ahead forecast of "cpiz" inflation taken from the Livingston Survey is interpolated at quarterly frequency. 


\section{References}

Aiyagari, S. Rao, Lawrence J. Christiano, and Martin Eichenbaum, 1992, “The Output, Employment, and Interest Rate Effects of Government Consumption," Journal of Monetary Economics, Vol. 30 (October), pp. 73-86.

Alesina, Alberto, Silvia Ardagna, Roberto Perotti, and Fabio Schiantarelli, 2002, "Fiscal Policy, Profits, and Investment," American Economic Review, Vol. 92 (June), pp. 571-589. , and Roberto Perotti, 1997, "Fiscal Adjustments in OECD Countries: Composition and Macroeconomic Effects," IMF Staff Papers, Vol. 44 (June), pp. 210-48.

Andrews, Donald W. K., and Werner Ploberger, 1994, "Optimal Tests When a Nuisance Parameter Is Present Only Under the Alternative," Econometrica, Vol. 62 (November), pp. 1383-414.

Aschauer, David A., 1989, “Is Public Expenditure Productive?" Journal of Monetary Economics, Vol. 23 (March), pp. 177-200.

Bai, Jushan, 1997, "Estimating Multiple Breaks One at a Time," Econometric Theory, Vol. 13 (June), pp. 315-52.

Ball, Laurence, Douglas W. Elmendorf, and N. Gregory Mankiw, 1998, "The Deficit Gamble," Journal of Money, Credit, and Banking, Vol. 30 (November), pp. 700-20.

— N. Gregory Mankiw, and David Romer, 1988, “The New Keynesian Economics and the Output-Inflation Trade-Off," Brookings Papers on Economic Activity: 1, Brookings Institution, pp. 1-65.

Barro, Robert J., 1974, “Are Government Bonds Net Wealth,” Journal of Political Economy, Vol. 82 (November/December), pp. 1095-117.

_ 1981, "Output Effects of Government Purchases," Journal of Political Economy, Vol. 89 (December), pp. 1086-121.

— , and Xavier Sala-ì-Martin, 1992, "Public Finance in Models of Economic Growth," Review of Economic Studies, Vol. 59 (October), pp. 645-61.

Barry, Frank, and Michael B. Devereux, 1995, “The 'Expansionary Fiscal Contraction' Hypothesis: A Neo-Keynesian Analysis," Oxford Economic Papers, Vol. 47 (April), pp. 249-64.

—, and Michael B. Devereux, 2003, "Expansionary Fiscal Contraction: A Theoretical Exploration," Journal of Macroeconomics, Vol. 25 (March), pp. 1-23.

Baxter, Marianne, and Robert G. King, 1993, "Fiscal Policy in General Equilibrium," American Economic Review, Vol. 83 (June), pp. 315-34.

Bayoumi, Tamim, and Paul R. Masson, 1998, "Liability-Creating Versus Non-Liability-Creating Fiscal Stabilization Policies: Ricardian Equivalence, Fiscal Stabilization, and EMU," Economic Journal, Vol. 108 (July), pp. 1026-45.

Bernanke, Ben, and Alan Blinder, 1992, "The Federal Funds Rate and the Channels of Monetary Transmission," American Economic Review, Vol. 82 (September), pp. 901-21. 
Bertola, Giuseppe, and Allan Drazen, 1993, “Trigger Points and Budget Cuts: Explaining the Effects of Fiscal Austerity," American Economic Review, Vol. 83 (March), pp. 11-26.

Blanchard, Oliver J., 1985, "Debt, Deficits, and Finite Horizons," Journal of Political Economy, Vol. 93 (April), pp. 223-47.

— Changes in Government Spending and Taxes on Output," Quarterly Journal of Economics, Vol. 117 (November), pp. 1329-68.

Burnside, Craig, Martin Eichenbaum, and Jonas Fisher, 2003, "Fiscal Shocks and Their Consequences," NBER Working Paper No. 9772 (Cambridge, Massachusetts: National Bureau of Economic Research).

Canzoneri, Matthew B., and Harris Dellas, 1998, "Real Interest Rates and Central Bank Operating Procedures," Journal of Monetary Economics, Vol. 42 (December), pp. 471-94.

Catão, Luis, and Marco E. Terrones, 2003, “Fiscal Deficits and Inflation,” IMF Working Paper 03/65, (Washington: International Monetary Fund).

Choi, Woon Gyu, 1999, “Asymmetric Liquidity Effects Across Monetary Policy Stances," Journal of Money, Credit, and Banking, Vol. 31 (Part 1, August), pp. 386-416.

_ 2002, "Inverted Fisher Hypothesis: Inflation Forecastability and Asset Substitution," IMF Staff Papers, Vol. 49, No. 2, pp. 212-41.

Christiano, Lawrence J., and Martin Eichenbaum, 1992, "Current Real-Business-Cycle Theories and Aggregate Labor-Market Fluctuations," American Economic Review, Vol. 82 (June), pp. $430-50$.

and Charles Evans, 1996, "The Effects of Monetary Policy Shocks: Evidence from the Flow of Funds," Review of Economics and Statistics, Vol. 78 (February), pp. 16-34.

Clarida, Richard, Jordi Galí, and Mark Gertler, 2000, "Monetary Policy Rules and Macroeconomic Stability: Evidence and Some Theory," Quarterly Journal of Economics, Vol. 115 (February), pp. 147-80.

Davies, Robert B., 1987, "Hypothesis Testing When a Nuisance Parameter Is Present Only Under the Alternative," Biometrika, Vol. 74 (No. 1), pp. 33-43.

Davig, Troy, Eric M. Leeper, and Hess Chung, 2004, "Monetary and Fiscal Policy Switching," NBER Working Paper No. 10362 (Cambridge, Massachusetts: National Bureau of Economic Research).

Devereux, Michael B., and David R. F. Love, 1995, "The Dynamic Effects of Government Spending Policies in a Two-Sector Endogenous Growth Model," Journal of Money, Credit, and Banking, Vol. 27 (February), pp. 232-56.

Durlauf, Steven N., and Paul A. Johnson, 1995, "Multiple Regimes and Cross-Country Growth Behavior," Journal of Applied Econometrics, Vol. 10 (October-December), pp. 365-84.

Dwyer, Gerald P., Jr., 1982, “Inflation and Government Deficits," Economic Inquiry, Vol. 20 (July), pp. 315-29. 
Evans, Paul, 1985, “Do Large Deficits Produce High Interest Rates?” American Economic Review, Vol. 75 (March), pp. 68-87.

1987, "Interest Rates and Expected Future Budget Deficits in the United States," Journal of Political Economy, Vol. 95 (February), pp. 34-58.

1988, "Are Consumers Ricardian? Evidence for the United States," Journal of Political Economy, Vol. 96 (October), pp. 983-1004.

and Georgios Karras, 1998, "Liquidity Constraints and the Substitutability between Private and Government Consumption: The Role of Military and Non-military Spending," Economic Inquiry, Vol. 36 (April), pp. 203-14.

Fatás, Antonio, and Ilian Mihov, 2003, "The Case for Restricting Fiscal Policy Discretion," Quarterly Journal of Economics, Vol. 118 (November), pp. 1419-47.

Fischer, Stanley, Ratna Sahay, and Carlos Végh, 2002, "Modern Hyper-and High Inflations," Journal of Economic Literature, Vol. 40 (September), pp. 837-80.

Garcia, René, and Pierre Perron, 1996, "An Analysis of the Real Interest Rate under Regime Shifts," Review of Economics and Statistics, Vol. 78 (February), pp. 111-25.

Giavazzi, Francesco, Tullio Jappelli, and Marco Pagano, 2000, "Searching for Non-linear Effects of Fiscal Policy: Evidence from Industrial and Developing Countries," European Economic Review, Vol. 44 (June), pp. 1259-89.

Granger, Clive W. J., and Timo Teräsvirta, 1993, Modelling Nonlinear Economic Relationships (New York: Oxford University Press).

Hansen, Bruce E., 1996, "Inference When a Nuisance Parameter is Not Identified Under the Null Hypothesis," Econometrica, Vol. 64 (March), pp. 413-30.

— 1999, "Threshold Effects in Non-Dynamic Panels: Estimation, Testing, and Inference," Journal of Econometrics, Vol. 93 (December), pp. 345-68.

_ , 2000, "Sample Splitting and Threshold Estimation," Econometrica, Vol. 68 (May), pp. 575-603.

Hemming, Richard, Michael Kell, and Selma Mahfouz, 2002, "The Effectiveness of Fiscal Policy in Stimulating Economic Activity-A Review of the Literature," IMF Working Paper 02/208, (Washington: International Monetary Fund).

Koelln, Kenneth, Mark Rush, and Doug Waldo, 1996, "Do Government Policy Multipliers Decrease with Inflation?” Journal of Monetary Economics, Vol. 38 (December), pp. 495505.

Koenig, Evan F., and Jim Dolmas, 2003, "Monetary Policy in a Zero-Interest-Rate Economy," Southwest Economy, No. 4 (July/August), Federal Reserve Bank of Dallas, pp. 1-6.

Kormendi, Roger C., 1983, "Government Debt, Government Spending, and Private Sector Behavior," American Economic Review, Vol. 73 (December), pp. 994-1010.

Leeper, Eric M., Christopher A. Sims, and Tao Zha, 1996, "What Does Monetary Policy Do?" Brookings Papers on Economic Activity: 2, Brookings Institution, pp. 1-78. 
Mankiw, N. Gregory, 1987, “Government Purchases and Real Interest Rates,” Journal of Political Economy, Vol. 95 (April), pp. 407-19.

— 2000, "The Savers-Spenders Theory of Fiscal Policy," American Economic Review, Papers and Proceedings, Vol. 90 (May), pp. 120-25.

Perotti, Roberto, 1999, "Fiscal Policy in Good Times and Bad," Quarterly Journal of Economics, Vol. 114 (November), pp. 1399-436.

_ , 2002, "Estimating the Effects of Fiscal Policy in OECD Countries," Working Paper (Milan: European University Institute).

Pesaran, M. Hashem, and Simon Potter, 1997, "A Floor and Ceiling Model of U.S. Output," Journal of Economic Dynamics and Control, Vol. 21 (May), pp. 661-95.

Ramey, Valerie A., and Matthew D. Shapiro, 1998, "Costly Capital Reallocation and the Effects of Government Spending," Carnegie Rochester Conference Series on Public Policy, Vol. 48 (June), pp. 145-94.

Reinhart, Carmen M., Kenneth S. Rogoff, and Miguel A. Savastano, 2003, "Debt Intolerance," Brookings Papers on Economic Activity: 1, Brookings Institution, pp. 1-74.

Runkle, David E., 1987, "Vector Autoregression and Reality," Journal of Business and Economic Statistics, Vol. 5 (October), pp. 437-53.

Sutherland, Alan, 1997, "Fiscal Crises and Aggregate Demand: Can High Public Debt Reverse the Effects of Fiscal Policy?" Journal of Public Economics, Vol. 65 (August), pp. 14762.

Tanzi, Vito, and Howell H. Zee, 1997, "Fiscal Policy and Long-Run Growth," IMF Staff Papers, Vol. 44 (June), pp. 179-209.

Tong, Howell, 1990, Non-Linear Time Series: A Dynamic System Approach (New York: Oxford University Press). 